\title{
HISTORIC MEASUREMENTS OF RADIOCARBON IN NEW ZEALAND SOILS
}

\author{
K. R. LASSEY, ${ }^{1}$ K. R. TATE, ${ }^{2}$ R. J. SPARKS ${ }^{3}$ and J. J. CLAYDON ${ }^{4}$
}

\begin{abstract}
Extensive measurements of radiocarbon have been used in New Zealand since the mid-1960s to follow carbon (C) movement and turnover in soils. We present here unpublished radiocarbon $\left({ }^{14} \mathrm{C}\right)$ measurements on a range of eight New Zealand soils with details of the sites, ecosystems, climates, soil descriptions and associated analytical data. An overview is also given of published ${ }^{14} \mathrm{C}$ measurements on soils, and the use of these measurements to model soil $\mathrm{C}$ turnover.
\end{abstract}

\section{INTRODUCTION}

New Zealand stretches $c a .2000 \mathrm{~km}$ along a north-south axis, spanning from $34^{\circ}$ to $47^{\circ} \mathrm{S}$ in the southwest Pacific. The country is more remote from its nearest neighbor than any other global landmass. This isolation coupled with a high degree of climatic, geological, soil and biological diversity compressed into just $270,000 \mathrm{~km}^{2}$, and the relative freedom from industrial pollution, provide unique opportunities for investigating surface-atmosphere exchange processes of global significance.

Furthermore, relatively undisturbed remnants of indigenous ecosystems of great antiquity are available for direct comparison with the introduced pastures and planted forests that replaced them over large areas, particularly of lowland New Zealand. It is against this background that in the early 1960s New Zealand nuclear and soil scientists recognized the opportunities for investigating these surface-atmosphere exchange processes (Rafter et al. 1965), provided by the then rapidly rising atmospheric concentration of radiocarbon from nuclear weapons tests that had commenced in 1954. In 1962, the New Zealand Radiocarbon Laboratory (NZRL), which was part of DSIR's Institute of Nuclear Sciences until July 1992, began analyzing anthropogenic ${ }^{14} \mathrm{C}$ in New Zealand soils. The first systematic mapping and classification of New Zealand soils was being concluded at this time (New Zealand Soil Bureau 1968), so that a representative range of well characterized sites and soils was immediately available for investigating soil dynamic processes, including rates of organic matter turnover. This research, using well-defined soil sequences to investigate the main soil forming factors (e.g., Stevens and Walker 1970; Jackman 1964), soon revealed the dynamic character of soil organic matter (SOM), and illustrated the unique opportunities New Zealand offered for understanding and quantifying the processes of ecosystem development. Thus, the scene was set for using the ${ }^{14} \mathrm{C}$ enrichment of the biosphere through photosynthesis to trace the pathways, and measure the fluxes, of $C$ in soil. Subsequently, through a program of extensive measurements of $\delta^{13} C$ and $\Delta^{14} \mathrm{C}$ in New Zealand soils and plants that followed, it eventually became possible to model biogeochemical pathways for the movement and turnover of C in soil (Rafter and Stout 1970; O'Brien and Stout 1978; O’Brien et al. 1981; O'Brien 1984, 1986).

Our aims in this report are 1) to list unpublished $\Delta^{14} \mathrm{C}$ and $\delta^{13} \mathrm{C}$ measurements made on New Zealand soil samples from eight profiles that have been well described and analyzed for their chemical and physical properties, and 2) to review briefly research previously published that used anthropogenic ${ }^{14} \mathrm{C}$ to investigate the dynamics of soil organic $\mathrm{C}$.

\footnotetext{
${ }^{1}$ National Institute of Water and Atmospheric Research, P.O. Box 14-901, Wellington, New Zealand

${ }^{2}$ Landcare Research New Zealand, Private Bag 11-052, Palmerston North, New Zealand

${ }^{3}$ Institute of Geological and Nuclear Sciences, P.O. Box 31-312, Lower Hutt, New Zealand

${ }^{4}$ Landcare Research New Zealand, Private Bag 3127, Hamilton, New Zealand
} 


\section{METHODS}

\section{Sites and Soils}

The eight sites (Fig. 1) and soils listed under "Summary of Unpublished ${ }^{14} \mathrm{C}$ Measurements on New Zealand Soils" reflect the wide diversity of climates and soil types represented in New Zealand. Descriptions are given for each of the eight sites and soils listed. Analytical data for $\Delta^{14} \mathrm{C}, \delta^{13} \mathrm{C}$ and a range of soil chemical and physical properties are presented by horizon; designations for soil horizons follow the convention of Clayden and Hewitt (1989).

\section{Analytical Methods and Definitions}

The $\mathrm{C}$ isotope results reported here were all obtained by stable-isotope mass spectrometry and by gas-counting techniques made on pretreated soils. The pretreatment comprises a hot-water wash, acid treatment (usually $2 \%$ phosphoric acid to remove carbonates), and water rinse. Values for ${ }^{13} \mathrm{C} /$ ${ }^{12} \mathrm{C}$ ratios and for ${ }^{14} \mathrm{C} /\left({ }^{12} \mathrm{C}+{ }^{13} \mathrm{C}\right)$ are expressed relative to standards after Craig (1953) and Stuiver and Polach (1977), respectively, by Equations (1)-(3).

$$
\begin{gathered}
\delta^{13} \mathrm{C}(\%)=1000\left[\left(R_{13} / R_{\mathrm{o}}\right)-1\right] \\
\left(1+\frac{\Delta^{14} \mathrm{C}}{1000}\right)=\left(1+\frac{\delta^{14} \mathrm{C}}{1000}\right)\left(\frac{975}{\left(1000+\delta^{13} \mathrm{C}\right)}\right)^{2} \\
\delta^{14} \mathrm{C}(\%)=1000\left[\left(R_{14} / R_{\text {std }}\right)-1\right] .
\end{gathered}
$$

In these equations, $R_{13}$ and $R_{\mathrm{o}}$ are the ${ }^{13} \mathrm{C} /{ }^{12} \mathrm{C}$ ratios in the soil C samples and isotope standard (PeeDee Belemnite, or PDB), respectively; $R_{14} / R_{\text {std }}$ is the ${ }^{14} \mathrm{C}$ content of the sample per gram of C, decaycorrected to the time of sampling, relative to that for the NIST radiometric standard $(0.95$ oxalic acid, HOxI), decay-corrected back to 1950 . By convention, $\delta^{13} \mathrm{C}, \delta^{14} \mathrm{C}$ and $\Delta^{14} \mathrm{C}$ are expressed in \%o. Since in most New Zealand ecosystems soil $\delta^{13} \mathrm{C}$ values are consistently close to $-25 \%$, there is no significant numerical distinction between $\Delta^{14} \mathrm{C}$ and $\delta^{14} \mathrm{C}$.

\section{Soil Chemical and Physical Analyses}

The methods for preparing soil samples for analysis, and the analytical methods themselves, are fully described by Blakemore et al. (1987). Carbon contents (wt\%) were determined by wet oxidation (Metson et al. 1979) prior to 1967, and subsequently by dry combustion (Blakemore et al. 1987). Although microbial biomass was not measured on the soil samples listed, measurements have been reported for some corresponding topsoils as follows: Carrick, Tima (Ross et al. 1980); Judgeford (Ross et al. 1990); Egmont (Ross 1992). The isotope, and soil chemical and physical data were largely retrieved from the NZRL archives, and the National Soils' Database, respectively.

\section{RESULTS}

\section{Summary of Unpublished ${ }^{14} \mathrm{C}$ Measurements on New Zealand Soils}

The locations of the sites for the eight soils listed are shown in Figure 1, together with sites for which $\Delta^{14} \mathrm{C}$ and $\delta^{13} \mathrm{C}$ measurements have already been published.

For each of the eight soils, we present two tabulations. The first contains site information, including location, climate, site, geology, land use, vegetation and soil classification, as well as a brief description of the soil by horizon. The second tabulation presents the isotope, soil chemical and physical analyses, along with explanatory notes as appropriate. All soil samples are identified by two laboratory codes, one for the isotope analyses designated "NZ", and the other, "SB", for the soil data. In 


\begin{tabular}{|r|l|c|l||}
\hline & Soil Name & Lab No. & \multicolumn{1}{|c|}{ Relerenco } \\
\hline \hline 1 & Waipoua & SB09323 & \\
\hline 2 & Thoi & SB08848 & Stout, 1983. \\
\hline 3 & Rotomahana & SBO7672 & \\
\hline 4 & Taupo & & Goh ot al, 1977. \\
\hline 5 & Egmont & SB07597 & \\
\hline 6 & Tokomaru & & Goh ot al, 1977. \\
\hline 7 & Dune Sand & & Goh ot al, 1976. \\
\hline 8 & Koputaroa & & Goh ot al, 1976. \\
\hline 9 & Kaitoke & & Tatw, 1972. \\
\hline 10 & Judgetord & SBO7536 & $\begin{array}{l}\text { Ratber \& Stout, 1970; } \\
\text { Stout \& O'Brien, 1972; } \\
\text { Goh ot al, 1977; } \\
\text { Stout \& O'Brien, 1978; } \\
\text { O'Brion, 1984; } \\
\text { Goh ot al, 1986. }\end{array}$ \\
\hline 11 & Silverstream & & O'Brien, 1984. \\
\hline
\end{tabular}

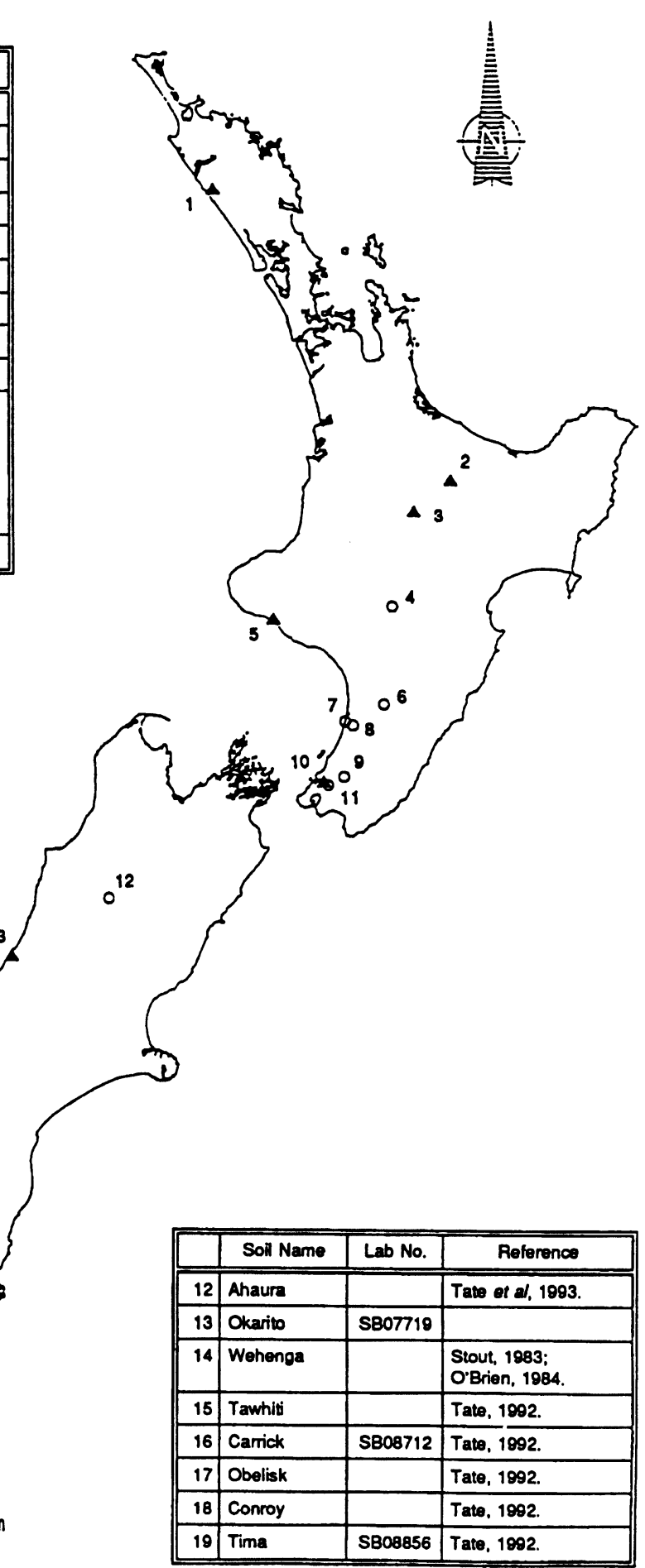

Fig. 1. Map of New Zealand (latitudes from 34 to $47^{\circ} \mathrm{S}$ ) showing the location of North and South Island sites and soils (A) described in this report. Sites where isotope data for soils has previously been published (o) are also shown. 
most cases, the $\Delta^{14} \mathrm{C}$ and $\delta^{13} \mathrm{C}$ measurements were made on the same soil samples as for the chemical and physical analyses. The exception was the Tihoi soil (Fig. 1, site 2), where the $C$ isotope analyses reported are for soil samples from a nearby site also under pasture. The horizons analyzed in the Rotomahana soil for $\Delta^{14} \mathrm{C}$ and $\delta^{13} \mathrm{C}$ straddle the boundary between the base of the contemporary soil, formed on volcanic mud erupted in 1886, and the soil beneath. Although many measurements of $\Delta^{14} \mathrm{C}$ and $\delta^{13} \mathrm{C}$ have been made, and reported, on Judgeford soils (see site summary in Fig. 1), the data presented here for a full profile has not been reported previously. Precisions for the $\delta^{13} \mathrm{C}$ isotope data are typically $\pm 0.1 \%$ (standard deviation).

\section{OVERVIEW OF PUBLISHED ${ }^{14} \mathrm{C}$ MEASUREMENTS ON NEW ZEALAND SOILS}

Several factors including climate, ecosystem and soil type, resource quality and soil biology, together regulate the turnover of SOM. The effects of some of these factors on organic matter turnover have been investigated in New Zealand soils using natural ${ }^{14} \mathrm{C}$ enrichment.

\section{Climate}

Stout and O'Brien (1972) contrasted the ${ }^{14} \mathrm{C}$ enrichment of the litter and soils in a warm temperate New Zealand kauri (Agathis Australis) forest (latitude $36^{\circ} \mathrm{S}$ ) with two topsoils in a tropical mixed kauri-broadleaved forest in New Hebrides $\left(19^{\circ} \mathrm{S}\right)$. They concluded from the high level of ${ }^{14} \mathrm{C}$ found in the two tropical topsoils, coupled with their relatively thin litter layers compared to the temperate forest, that $\mathrm{C}$ was cycling much more rapidly in the former. However, a highly productive temperate New Zealand topsoil was enriched with ${ }^{14} \mathrm{C}$ to a similar extent as the two tropical topsoils.

More recently, the ${ }^{14} \mathrm{C}$ measured in five profiles of a soil climosequence in native tussock grassland in South Island, New Zealand, first published by Stout and Rafter (1978), was used in conjunction with total soil $\mathrm{C}$ contents to investigate the possible effects of global warming on soil $\mathrm{C}$ turnover (Tate 1992). The climates across the sequence ranged from cold to warm temperate. A soil $\mathrm{C}$ turnover model (O'Brien 1984) indicated that turnover rates for three of the soils were in the range expected for New Zealand grassland soils. For two of the soils, however, much lower levels of ${ }^{14} \mathrm{C}$ indicated unexpectedly slow turnover rates that were attributed to a memory effect from the former beech forest that grew on these sites in prehistoric times. Local site factors including intermittent waterlogging may also have impeded decomposition processes and affected the overall soil $\mathrm{C}$ balance (Tate et al. 1995).

\section{Ecosystem Type}

The types of vegetation and soil can have a strong influence on the pattern of ${ }^{14} \mathrm{C}$ distribution in soils (Rafter and Stout 1970). Whereas $\Delta^{14} \mathrm{C}$ in pasture grasses reflected the composition of atmospheric $\mathrm{CO}_{2}$, during the period of rapid change in the $1960 \mathrm{~s}, \Delta^{14} \mathrm{C}$ in beech leaves lagged behind that of the atmosphere. Rafter and Stout (1970) attributed this lower $\Delta^{14} \mathrm{C}$ to mixing of photosynthesized $\mathrm{C}$ during a two-year period of beech leaf growth. $\Delta^{14} \mathrm{C}$ in the beech litter was measured annually for seven years from 1953, and again from 1964 until 1967. Comparison of the soil profiles beneath these two vegetation types indicated a different distribution pattern of $\Delta^{14} \mathrm{C}$. The upper soil horizon under the pasture was only slowly enriched with "bomb" ${ }^{14} \mathrm{C}$, and the subsoil had very low $\Delta{ }^{14} \mathrm{C}$ values. By contrast, the litter horizon of the southern beech (near site 11, Fig. 1), and the deeper soil horizons, showed that appreciable ${ }^{14} \mathrm{C}$ enrichment had occurred. Thus, $\mathrm{C}$ entering the beech profile was more mobile than that entering the pasture profile. In the latter, plant residues were decomposed upon entering the soil, and released more rapidly back to the atmosphere as $\mathrm{CO}_{2}$. Rafter and Stout 
(1970) presented ${ }^{13} \mathrm{C}$ and ${ }^{14} \mathrm{C}$ data for five different soil types, although not all horizons were analyzed, and little accompanying site and soil data were recorded.

In a comparison of two adjacent ecosystems on similar soil types near Wellington-an old-growth, lowland southern beech forest and a productive pasture-Tate (1972) found that ${ }^{14} \mathrm{C}$ was again restricted to the topsoil under the pasture, but occurred throughout the soil profile (to $0.38 \mathrm{~m}$ depth) under the beech forest. The ${ }^{14} \mathrm{C}$ in the soils and their chemically separated fractions (humic and fulvic acids) were used to confirm that soil polyphenols in the subsoil beneath the pasture were derived predominantly from the original beech forest. The ${ }^{14} \mathrm{C}$ in the soil beneath this and a nearby beech forest are discussed in more detail elsewhere (Stout and O'Brien 1972; Stout, et al. 1976; O'Brien 1984).

More recently, Tate et al. (1993) used $\Delta^{14} \mathrm{C}$ in soil profiles beneath an old-growth southern beech forest together with soil chemical, physical and biological data to calculate $C$ turnover rates. The accumulation of old $\mathrm{C}$ in these soils was attributed to the effects on soil $\mathrm{C}$ turnover of a long history of soil mixing by tree overturn in this ancient forest. This process is not observed in grassland soils.

\section{Soil Type}

The age of SOM appears to be more closely related to soil type, and soil forming processes, than to climate (Stout et al. 1981). This was shown in investigations of a chronosequence of New Zealand soils developed on wind-blown sand. Soil ages along the chronosequence ranged from 20 to $c a$. $10,000 \mathrm{yr}$ (Goh and Stout 1972; Goh et al. 1976). The mass of total organic C in the soil profiles and the carbon isotope composition of specific soil horizons were presented in these investigations. The rate of accumulation of soil organic $\mathrm{C}$ was rapid in the first $500 \mathrm{yr}$ of soil formation, with a considerable range in the age of the SOM as a function of depth within a profile. The younger soils were more enriched with ${ }^{14} \mathrm{C}$, with topsoils more enriched than subsoils (Goh and Stout 1972). Goh et al. (1976) attempted to interpret ${ }^{14} \mathrm{C}$ levels in the classical humus fractions of some of these soils (humic and fulvic acids, and humins) in terms of possible genetic relationships between them, but the outcome was mainly equivocal.

In a closely related study, Goh et al. (1977) found that the ${ }^{14} \mathrm{C}$ levels in the humus fractions varied both within and among soil types, as well as between topsoils and subsoils. They studied a range of soil types from several sites in grasslands of mainly low to medium fertility. These soil types included a Fluvaquent, Typic Fragiaqualf, Typic Dystrochrept and Umbric Vitrandept (Soil Survey Staff 1992). It appeared that ${ }^{14} \mathrm{C}$ levels were primarily determined by the stage of decomposition of the organic matter, rather than by soil type. These studies on soil humus fractions have added to the weight of evidence (O'Brien et al. 1981) indicating that these classical fractions have limited value in unraveling the complex biological pathways involved in SOM turnover. The effect of soil type on organic matter turnover in New Zealand is expressed most strongly in those soils in North Island containing short-range order minerals, e.g., allophane (Jackman 1964). Current research (K. R. Tate, unpublished results) seeks to quantify the influence of allophane and ferrihydrite on organic matter turnover, and for this purpose, the distribution of "bomb" ${ }^{14} \mathrm{C}$ in three volcanic ash soils is being investigated.

\section{Soil Biological Activity}

Earthworms, both native and introduced, have an important influence on New Zealand soils by comminuting and incorporating plant residues, thereby accelerating organic matter turnover rates. Stout (1983) and O'Brien (1984) used soil ${ }^{14} \mathrm{C}$ measurements on different soil types in attempts to 
quantify the effect of earthworms at sites with known populations. In the absence of earthworms there was little evidence for downward movement of ${ }^{14} \mathrm{C}$ in the soil and decomposition rates were slow. Stout (1983) reported total masses of soil organic C, ${ }^{14} \mathrm{C}$ and ${ }^{13} \mathrm{C}$ for several Tihoi (Site 2, Fig. 1) and Wehenga soil profiles without worms and with known worm populations. These studies showed that the presence of earthworms had increased topsoil organic matter contents, and accelerated decomposition including that of old C. O'Brien (1984) modeled the turnover of soil C using the profile distributions of "bomb" ${ }^{14} \mathrm{C}$ in the soil profiles, and found that in the South Island Wehenga soil the presence of earthworms had caused organic matter turnover rates to increase fivefold.

\section{Modeling SOM Turnover}

Much of the research in New Zealand on the use of "bomb" ${ }^{14} \mathrm{C}$ to investigate soil C turnover has involved investigating Judgeford soils near Wellington. O'Brien and Stout (1978) developed a steady-state model to represent organic $\mathrm{C}$ turnover, and used "bomb" ${ }^{14} \mathrm{C}$ and soil organic $\mathrm{C}$ measurements in Judgeford soil profiles sampled over a ca. 15 -yr period to evaluate the model parameters: $\mathrm{C}$ input, decomposition time and downward diffusivity in the soil profile. Estimates of these model parameters have subsequently been made for five New Zealand pasture soils and a forest soil (O'Brien 1984), five soils in native tussock grassland (Tate 1992), and an old-growth southern beech forest (Tate et al. 1993). Evidence from detailed ${ }^{14} \mathrm{C}$ and ${ }^{13} \mathrm{C}$ measurements made on a soil core to the base of the Judgeford soil (Goh et al. 1984), and in a nearby soil (O'Brien 1986), supported the hypothesis in the model that the concentration of old (inert) $\mathrm{C}$ - possibly polymethylene $\mathrm{C}$ (Theng et al. 1992)-remains constant with depth in the profile.

\section{ACKNOWLEDGMENTS}

Special acknowledgments are due to the late Dr. T. A. Rafter and Dr. B. J. O'Brien, the first and last directors of the former DSIR Institute of Nuclear Sciences, and the late Dr. J. D. Stout of the former DSIR Soil Bureau, for their pioneering research work using anthropogenic ${ }^{14} \mathrm{C}$ to follow the pathways, and quantify C flows in the biosphere. Mr. B. Clayden, and Mr. J. Whitton of Landcare Research New Zealand, assisted with soil classification and horizon notations, and clay mineral identifications, respectively.

\section{REFERENCES}

Blakemore, L. C., Searle, P. L. and Daly, B. K. 1987 Methods for chemical analysis of soils. New Zealand Soil Bureau Scientific Report 80: 103 p.

Clayden, B. and Hewitt, A. E. 1989 Horizon notation for New Zealand soils. DSIR Division of Land and Soil Sciences Report 1: $30 \mathrm{p}$.

Craig, H. 1953 The geochemistry of stable carbon isotopes. Geochimica et Cosmochimica Acta 3: 53-92.

Goh, K. M., Rafter, T. A., Stout, J. D. and Walker, T. W. 1976 The accumulation of soil organic matter and its carbon isotope content in a chronosequence of soils developed on aeolian sand in New Zealand. Journal of Soil Science 27: 89-100.

Goh, K. M. and Stout, J. D. 1972 Radiocarbon enrichment and the turnover of soil organic matter in a chronosequence of soils developed on wind-blown sand in New Zealand. In Rafter, T. A. and Grant-Taylor, T., eds., Proceedings of the 8th International Conference on ${ }^{14} \mathrm{C}$ Dating. Wellington, New Zealand, Royal Society of New Zealand: E67-E81.

Goh, K. M., Stout, J. D. and O'Brien, B. J. 1984 The significance of fractionation in dating the age and turnover of soil organic matter. New Zealand Journal of Science 27: 69-72.

Goh, K. M., Stout, J. D. and Rafter, T. A. 1977 Radiocarbon enrichment of soil organic matter fractions in New Zealand soils. Soil Science 123: 385-391

Jackman, R. H. 1964 Accumulation of organic matter in some New Zealand soils under permanent pasture 1. Patterns of change of organic carbon, nitrogen, sulphur and phosphorus. New Zealand Journal of Agricultural Research 7: 445-471.

Metson, A. J., Blakemore, L. C. and Rhoades, D. A. 1979 Methods for the determination of soil organic carbon: 
A review, and application to New Zealand soils. New Zealand Journal of Science 22: 205-228.

NZ Soil Bureau 1968 Soils of New Zealand. New Zealand Soil Bureau Bulletin 26(1): 142 p.

O'Brien, B. J. 1984 Soil organic carbon fluxes and turnover rates estimated from radiocarbon enrichments. Soil Biology and Biochemistry 16: 115-120.

1986 The use of natural and anthropogenic ${ }^{14} \mathrm{C}$ to investigate the dynamics of soil organic carbon. In Stuiver, M. and Kra, R., eds., Proceedings of the 12th International ${ }^{14} \mathrm{C}$ Conference. Radiocarbon $28(2 \mathrm{~A})$ : 358-362.

O'Brien, B. J. and Stout, J. D. 1978 Movement and turnover of soil organic matter as indicated by carbon isotope measurements. Soil Biology and Biochemistry 10: 309-317.

O'Brien, B. J., Stout, J. D. and Goh, K. M. 1981 The use of carbon isotope measurements to examine the movement of labile and refractory carbon in soil. In Flux of Organic Carbon by Rivers to the Oceans. Report on a Workshop in Woods Hole, Massachusetts. U.S. Department of Energy, CONF-80091401: 46-74.

Rafter, T. A., Martin, J. K. and Jackman, R. H. 1965 A study of the carbon-14 method in the interpretation of soil carbons. Institute of Nuclear Sciences Internal Report 591.

Rafter, T. A. and Stout, J. D. 1970 Radiocarbon measurements as an index of the rate of turnover of organic matter in forest and grassland ecosystems in New Zealand. In Olsson, I. U., ed., Radiocarbon Variations and Absolute Chronology, Proceedings of the 12th Nobel Symposium. New York, Wiley \& Sons: 401447.

Ross, D. J. 1992 Influence of sieve mesh size on estimates of microbial carbon and nitrogen by fumigation-extraction procedures in soils under pasture. Soil Biology and Biochemistry 24: 343-350.

Ross, D. J., Hart, P. B. S., Sparling, G. P. and August, J. A. 1990 Soil restoration under pasture after topsoil removal: Some factors influencing $\mathrm{C}$ and $\mathrm{N}$ mineralisation and measurements of microbial biomass. Plant and Soil 127: 49-59.

Ross, D. J., Tate, K. R., Cairns, A. and Pansier, E. A. 1980 Microbial biomass estimations in soils from tussock grasslands by three biochemical procedures. Soil Biology and Biochemistry 12: 375-383.

Soil Survey Staff 1992 Keys to Soil Taxonomy, 5th Edition, SMSS technical monograph 19. Blacksburg, Virginia, Pocohontas Press.

Stevens, P. R. and Walker, T. W. 1970 The chronosequence concept and soil formation. Quarterly Review of Biology 45: 333-350.

Stout, J. D. 1983 Organic matter turnover by earthworms. In Satchell, J. E., ed., Earthworm Ecology: From Darwin to Vermiculture. London, Chapman \& Hall: 3548.
Stout, J. D., Goh, K. M. and Rafter, T. A. 1977 Radiocarbon enrichment of soil organic fractions. In Povinec, P. and Usacev, S., eds., Proceedings of an International Conference on Low-Radioactivity Measurements and Applications. Bratislava, Czechoslovakia: 309-316.

1981 Chemistry and turnover of naturally occurring resistant organic compounds in soil. In Paul, E. A. and Ladd, J. N., eds., Soil Biochemistry 5. New York, Marcel Dekker: 1-73.

Stout, J. D. and O'Brien, B. J. 1972 Factors affecting radiocarbon enrichment in soil and the turnover of soil organic matter. In Rafter, T. A. and Grant-Taylor, T., eds., Proceedings of the 8th International Conference on ${ }^{14} \mathrm{C}$ Dating. Wellington, New Zealand, Roya! Society of New Zealand: E13-E26.

1978 Movement and turnover of soil organic matter as indicated by carbon isotope measurements. Soil Biology \& Biochemistry 10: 309-317.

Stout, J. D. and Rafter, T. A. 1978 The ${ }^{13} \mathrm{C} /{ }^{12} \mathrm{C}$ isotopic ratios of some New Zealand tussock grassland soils. In Robinson, B.W., ed., Stable Isotopes in the Earth Sciences. New Zealand DSIR, Wellington, New Zealand: 75-83,

Stout, J. D., Tate, K. R. and Molloy, L. F. 1976 Decomposition processes in New Zealand soils. In Anderson, J. M. and Macfadyen, A., eds., The Role of Terrestrial and Aquatic Organisms in Decomposition Processes. Oxford, Blackwell Scientific Publications: 96-144.

Stuiver, M. and Polach, H. A. 1977 Discussion: Reporting of ${ }^{14} \mathrm{C}$ data. Radiocarbon 19(3): 355-363.

Tate, K. R. 1972 Radiocarbon dating in studies of soil organic matter-vegetation relationships. In Rafter, T. A. and Grant-Taylor, T., eds., Proceedings of the 8th International Conference on ${ }^{14} \mathrm{C}$ Dating. Wellington, New Zealand, Royal Society of New Zealand: E27E38.

1992 Assessment, based on a climosequence of soils in tussock grasslands, of soil carbon storage and release in response to global warming. Journal of Soil Science 43: 697-707.

Tate, K. R., Parshotam, A. and Ross, D. J. 1995 Soil carbon storage and turnover in temperate forests and grasslands-a New Zealand perspective. Journal of Biogeography 22: 695-700.

Tate, K. R., Ross, D. J., O'Brien, B. J. and Kelliher, F. M. 1993 Carbon storage and turnover, and respiratory activity, in the litter and soil of an old-growth southern beech (Nothofagus) forest. Soil Biology and Biochemistry 25: 1601-1612.

Theng, B. K. G., Tate, K. R. and Becker-Heidmann, P. 1992 Towards establishing the age, location and identify of the inert soil organic matter of a spodosol. Zeitschrift Pflanzenernährung und Bodenkunde 155: 181-184. 
Site 1: Location and Soil Description

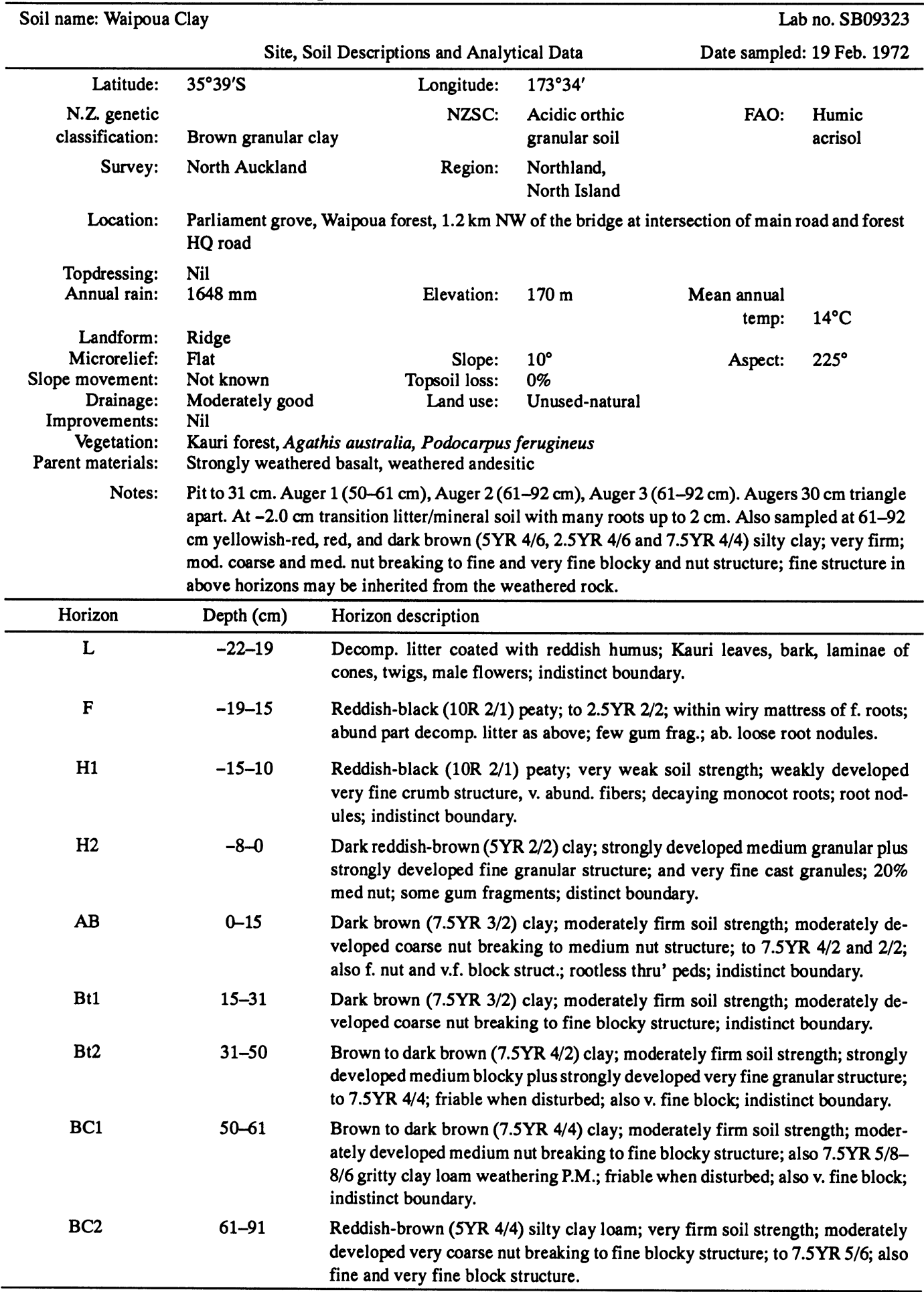


Site 1: Measurements

\begin{tabular}{|c|c|c|c|c|c|c|c|c|c|c|c|c|c|c|}
\hline \multirow{2}{*}{$\begin{array}{l}\text { S.B. } \\
\text { lab no. }\end{array}$} & \multirow{2}{*}{$\begin{array}{c}\text { N.Z. } \\
\text { lab no. }\end{array}$} & \multirow{2}{*}{$\begin{array}{c}\text { Horizon } \\
\text { desig. }\end{array}$} & \multirow{2}{*}{$\begin{array}{c}\text { Sample } \\
\text { depth } \\
\text { (cm) }\end{array}$} & \multicolumn{2}{|c|}{ Isotopes } & \multicolumn{9}{|c|}{ Chemical Properties } \\
\hline & & & & $\begin{array}{c}\Delta^{14} \mathrm{C} \\
\mathscr{S}_{0}\end{array}$ & $\begin{array}{c}\delta^{13} \mathrm{C} \\
\%_{00}\end{array}$ & $\begin{array}{l}\mathrm{C} \\
\%\end{array}$ & $\begin{array}{l}\mathbf{N} \\
\%\end{array}$ & $\mathrm{C} / \mathrm{N}$ & $\begin{array}{l}\mathrm{CEC} \dagger \\
\mathrm{me} \%\end{array}$ & \begin{tabular}{|c}
$\mathrm{pH}\left(\mathrm{H}_{2} \mathrm{O}\right)$ \\
dry soil
\end{tabular} & \begin{tabular}{|l|}
$\mathrm{pH}\left(\mathrm{H}_{2} \mathrm{O}\right)$ \\
moist soil \\
\end{tabular} & $\begin{array}{l}\text { Total P } \\
\text { mg \% }\end{array}$ & $\begin{array}{l}\text { Org. P } \\
\text { mg \% }\end{array}$ & $\begin{array}{c}\text { Inorg. P } \\
\mathrm{mg} \%\end{array}$ \\
\hline $9323 \mathrm{~A}$ & & $\mathrm{~L}$ & $-22-19$ & & & 50.0 & 0.83 & 60 & 79.2 & & 4.1 & 39 & & \\
\hline $9323 \mathrm{~B}$ & 1439 & $\mathbf{F}$ & $-19-15$ & $18.3 \pm 7.0$ & -25.2 & 49.0 & 1.21 & 40 & 130.5 & & 4.1 & 40 & & \\
\hline $9323 \mathrm{C}$ & 1440 & H1 & $-15-10$ & $-4.9 \pm 6.9$ & -25.2 & 50.0 & 1.29 & 39 & 125.5 & & 3.5 & 40 & & \\
\hline 9323D & 1443 & $\mathrm{H} 2$ & $-8-0$ & $-17.0 \pm 7.0$ & -24.0 & 19.0 & 0.66 & 29 & 57.7 & & 3.8 & & & \\
\hline $9323 \mathrm{E}$ & 1557 & $\overline{\mathrm{AB}}$ & $0-15$ & $-31.8 \pm 6.9$ & -25.7 & 7.8 & 0.32 & 24 & 34.9 & & 4.3 & & & \\
\hline $9323 \mathrm{~F}$ & 1573 & Bt1 & $15-31$ & $-35.1 \pm 6.8$ & -26.5 & 4.5 & 0.22 & 20 & 26.2 & & 4.8 & & & \\
\hline $9323 \mathrm{G}$ & 1574 & Bt2 & $31-50$ & $-72.2 \pm 6.7$ & -25.8 & 3.1 & 0.14 & 22 & 20.8 & & 4.7 & & & \\
\hline $9323 \mathrm{H}$ & & $\overline{\mathrm{BC} 1}$ & $50-61$ & & & 1.7 & 0.07 & 24 & 16.2 & & 4.7 & & & \\
\hline 9323I & & $\mathrm{BC2}$ & $61-92$ & & & 0.9 & 0.03 & * & 15.1 & & 4.9 & & & \\
\hline 9323J & & $\overline{B C 2}$ & $61-92$ & & & 1.2 & \begin{tabular}{|l|}
0.04 \\
\end{tabular} & * & 14.1 & & 4.7 & & & \\
\hline
\end{tabular}

\begin{tabular}{|c|c|c|c|c|c|c|c|c|c|c|}
\hline \multirow[b]{2}{*}{$\begin{array}{c}\text { S.B. } \\
\text { lab no. }\end{array}$} & \multirow[b]{2}{*}{$\begin{array}{c}\text { N.Z. } \\
\text { lab no. }\end{array}$} & \multirow[b]{2}{*}{$\begin{array}{c}\text { Horizon } \\
\text { desig. }\end{array}$} & \multirow[b]{2}{*}{$\begin{array}{c}\text { Sample } \\
\text { depth } \\
(\mathrm{cm})\end{array}$} & \multicolumn{6}{|c|}{ Physical-Mineralogical Properties } & \multirow[b]{2}{*}{ Comments } \\
\hline & & & & $\begin{array}{c}\text { Dry bulk } \\
\text { density } \\
t / \mathrm{m}^{3}\end{array}$ & $\begin{array}{l}\text { Stones } \\
(\% \mathrm{v} / \mathrm{v})\end{array}$ & $\begin{array}{c}\% \text { Sand } \\
2.0-0.02 \\
\mathrm{~mm}\end{array}$ & \begin{tabular}{|c|}
$\%$ Silt \\
$0.02-0.002$ \\
$\mathrm{~mm}$
\end{tabular} & $\begin{array}{c}\% \text { Clay } \\
<0.002 \\
\mathrm{~mm}\end{array}$ & $\begin{array}{l}\text { Clay minerals } \\
\text { (topsoil only) }\end{array}$ & \\
\hline $9323 \mathrm{~A}$ & & L & & 0.04 & & & & & 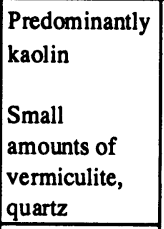 & $\begin{array}{l}\text { L, F, H litter horizon bulk densi- } \\
\text { ties (italics) are approximate, } \\
\text { est. from means for litters under } \\
\text { southern beech and mixed } \\
\text { podocarp/broadleaf forest. } \\
\text { Bulk densities (italics) for AB, } \\
\text { Bt horizons estimated from } 5\end{array}$ \\
\hline 9323B & 1439 & $\mathbf{F}$ & & 0.08 & & & & & & brown granular clay soils at \\
\hline $9323 \mathrm{C}$ & 1440 & $\mathrm{H} 1$ & & 0.08 & & & & & & similar depths. \\
\hline 9323D & 1443 & $\mathrm{H} 2$ & & 0.08 & & & & & & $\mathrm{AB}$ mean $=0.94$ std. dev. $=0.17$ \\
\hline $9323 \mathrm{E}$ & 1557 & $\overline{\mathrm{AB}}$ & & 0.94 & & & & & & Bt mean $=0.93$ std. dev. $=0.15$ \\
\hline 9323F & 1573 & Bt1 & & 0.93 & & & & & & Blank spaces in tables indicate \\
\hline $9323 \mathrm{G}$ & \begin{tabular}{|l|}
1574 \\
\end{tabular} & $\overline{B D}$ & & 0.93 & & & & & & no available data. \\
\hline $9323 \mathrm{H}$ & & $\mathrm{BC} 1$ & & & & & & & & {$\left[\begin{array}{l}\mathrm{C} / \mathrm{N} \text { ratio not calculated when } \\
\mathrm{N}<0.05\end{array}\right.$} \\
\hline 9323I & & $\mathrm{BC} 2$ & & & & & & & & †CEC = cation exchange capac- \\
\hline $9323 \mathrm{~J}$ & & $\mathrm{BC} 2$ & & & & & & & & ity; me $\%=\mathrm{c} \mathrm{mol}(+) \mathrm{kg}^{-1}$ \\
\hline
\end{tabular}

\section{Site 2: Location and Soil Description}

\begin{tabular}{|c|c|c|c|c|c|}
\hline \multicolumn{4}{|c|}{ Soil name: Tihoi Loamy Sand } & \multicolumn{2}{|c|}{ Lab no. SB08848 } \\
\hline & \multicolumn{3}{|c|}{ Site, Soil Descriptions and Analytical Data } & \multicolumn{2}{|c|}{ Date sampled: 27 Mar. 1973} \\
\hline Latitude: & $38^{\circ} 35^{\prime} \mathrm{S}$ & Longitude: & $175^{\circ} 57^{\prime}$ & & \\
\hline $\begin{array}{l}\text { N.Z. genetic } \\
\text { classification: }\end{array}$ & $\begin{array}{l}\text { Podzolized yellow- } \\
\text { brown pumice soil }\end{array}$ & NZSC: & $\begin{array}{l}\text { Humose orthic } \\
\text { podzol }\end{array}$ & FAO: & $\begin{array}{l}\text { Orthic } \\
\text { podzol }\end{array}$ \\
\hline Survey: & Soils of Taupo region & Region: & $\begin{array}{l}\text { Taupo, North } \\
\text { Island }\end{array}$ & & \\
\hline Location: & Lomond Road, $1 \mathrm{~km} \mathrm{e}$ & obsidian cuttin & cutting of old sc & quarry. & \\
\hline $\begin{array}{l}\text { Topdressing: } \\
\text { Annual rain: } \\
\text { Landform: }\end{array}$ & $\begin{array}{l}\text { Not known } \\
2000 \mathrm{~mm} \\
\text { In rolling country }\end{array}$ & Elevation: & $610 \mathrm{~m}$ & $\begin{array}{r}\text { Mean annual } \\
\text { temp: }\end{array}$ & $12^{\circ} \mathrm{C}$ \\
\hline $\begin{array}{r}\text { Microrelief: } \\
\text { Slope movement: } \\
\text { Drainage: } \\
\text { Improvements: } \\
\text { Vegetation: } \\
\text { Parent materials: } \\
\text { Notes: }\end{array}$ & $\begin{array}{l}\text { Flat } \\
\text { Not known } \\
\text { Well } \\
\text { Oversown, ploughed } \\
\text { Browntop, Yorkshire } \mathrm{f} \\
\text { Taupo pumice overlyir } \\
\text { Erosion - nil }\end{array}$ & $\begin{array}{r}\text { Slope: } \\
\text { Topsoil loss: } \\
\text { Land Use: } \\
\text { istles, White c } \\
\text { thered rhyoliti }\end{array}$ & $\begin{array}{l}4^{\circ} \\
0 \% \\
\text { Rough grazing } \\
\text { ver } \\
\text { tephra }\end{array}$ & Aspect: & $360^{\circ}$ \\
\hline
\end{tabular}


Site 2: Location and Soil Description(Continued)

\begin{tabular}{|c|c|c|}
\hline Horizon & Depth (cm) & Horizon description \\
\hline Ap & $0-9$ & $\begin{array}{l}\text { Black (10YR 2/1) loamy sand; very weak soil strength; weakly developed fine } \\
\text { granular plus weakly developed fine crumb structure; abundant live roots; } \\
\text { tending to } 10 \text { YR } 3 / 2 \text {; few fine lapilli; distinct irregular boundary. }\end{array}$ \\
\hline $\mathrm{Ea}$ & $11-9$ & $\begin{array}{l}\text { Greyish brown (10YR } 5 / 2) \text { fine sand; moderately weak soil strength; weakly } \\
\text { developed fine crumb plus weakly developed fine granular structure; many me- } \\
\text { dium and fine lapilli; distinct smooth boundary. }\end{array}$ \\
\hline $\mathrm{Bh}$ & $21-37$ & $\begin{array}{l}\text { Dark reddish brown (5YR 3/4) loamy sand; moderately weak soil strength; } \\
\text { weakly developed fine nut plus weakly developed fine granular structure; few } \\
\text { medium and fine lapilli; distinct smooth boundary. }\end{array}$ \\
\hline Bs & $40-50$ & $\begin{array}{l}\text { Strong brown ( } 7.5 \text { YR } 5 / 6) \text { gritty sand; moderately firm soil strength; massive; } \\
\text { distinct smooth boundary }\end{array}$ \\
\hline $2 \mathrm{Cu} 1$ & $52-78$ & $\begin{array}{l}\text { Yellowish brown (10YR } 5 / 8) \text { to } 7.5 \text { YR } 5 / 8 \text { (and much darker grey rhyolite) } \\
\text { pumice gravel; loose soil strength; single grain; Taupo lapilli; distinct irregular } \\
\text { boundary. }\end{array}$ \\
\hline $3 \mathrm{Cu} 2$ & $80-105$ & $\begin{array}{l}\text { Light yellowish brown }(2.5 \mathrm{Y} 6 / 4) \text { gritty sand; loose soil strength; massive } \\
\text { breaking to single grain; pumice gravel; firm in situ; sharp smooth boundary. }\end{array}$ \\
\hline $3 \mathrm{Cu} 3$ & $105-107$ & $\begin{array}{l}\text { Grey ( } 5 \text { Y 5/1) loamy sand; moderately firm soil strength; massive; (Rotongaio } \\
\text { Ash); sharp smooth boundary. }\end{array}$ \\
\hline $3 \mathrm{Cu} 4$ & $109-119$ & $\begin{array}{l}\text { Yellowish brown (10YR 5/4) gritty sandy loam; moderately weak soil strength; } \\
\text { weakly developed granular structure; greasy. }\end{array}$ \\
\hline
\end{tabular}

\section{Site 2: Measurements}

\begin{tabular}{|c|c|c|c|c|c|c|c|c|c|c|c|c|c|c|}
\hline \multirow{2}{*}{$\begin{array}{c}\text { S.B. } \\
\text { lab no. }\end{array}$} & \multirow{2}{*}{$\begin{array}{c}\text { N.Z. } \\
\text { lab no. }\end{array}$} & \multirow{2}{*}{$\begin{array}{c}\text { Horizon } \\
\text { desig. }\end{array}$} & \multirow{2}{*}{$\begin{array}{c}\text { Sample } \\
\text { depth } \\
(\mathrm{cm})\end{array}$} & \multicolumn{2}{|c|}{ Isotopes } & \multicolumn{9}{|c|}{ Chemical Properties } \\
\hline & & & & $\begin{array}{c}\Delta^{14} \mathrm{C} \\
\%_{0}\end{array}$ & $\begin{array}{c}\delta^{13} \mathrm{C} \\
\%_{00}\end{array}$ & $\begin{array}{l}\mathrm{C} \\
\%\end{array}$ & $\begin{array}{l}\mathbf{N} \\
\%\end{array}$ & $\mathrm{C} / \mathrm{N}$ & $\begin{array}{l}\text { CEC }+ \\
\text { me \% }\end{array}$ & $\begin{array}{c}\mathrm{pH}\left(\mathrm{H}_{2} \mathrm{O}\right) \\
\text { dry soil }\end{array}$ & $\begin{array}{l}\mathrm{pH}\left(\mathrm{H}_{2} \mathrm{O}\right) \\
\text { moist soil }\end{array}$ & $\begin{array}{c}\text { Total P } \\
\text { mg \% }\end{array}$ & $\begin{array}{l}\text { Org. P } \\
\text { mg \% }\end{array}$ & $\begin{array}{c}\text { Inorg. P } \\
\text { mg \% }\end{array}$ \\
\hline $8848 \mathrm{~A}$ & 5986 & Ap & $0-9$ & $142.8 \pm 4.4$ & -26.6 & \begin{tabular}{|l|}
4.6 \\
\end{tabular} & 0.30 & 15 & 13.5 & & 6.0 & 57 & 29 & 28 \\
\hline $8848 \mathrm{~B}$ & 5987 & $\mathrm{Ea}$ & $11-19$ & $58.6 \pm 5.8$ & -25.9 & \begin{tabular}{|l|}
4.1 \\
\end{tabular} & 0.31 & 13 & 12.3 & & 6.1 & 63 & 22 & 41 \\
\hline $8848 \mathrm{C}$ & & $\mathrm{Bh}$ & $21-37$ & & & 2.8 & 0.16 & 18 & 13.1 & & 6.2 & 43 & 21 & 22 \\
\hline $8848 \mathrm{D}$ & 5988 & Bs & $40-50$ & $0.4 \pm 7.2$ & $-25.9 \mid$ & 2.0 & 0.11 & 18 & 8.6 & & 6.1 & 39 & 12 & 27 \\
\hline $8848 \mathrm{E}$ & & $2 \mathrm{Cu} 1$ & $52-78$ & & & 0.8 & \begin{tabular}{|l|}
0.04 \\
\end{tabular} & * & 4.9 & & 6.4 & 40 & 2 & 38 \\
\hline $8848 \mathrm{~F}$ & & $3 \mathrm{Cu} 2$ & $80-105$ & & & \begin{tabular}{|l|}
0.7 \\
\end{tabular} & 0.03 & * & 3.7 & & 6.5 & 37 & 1 & 36 \\
\hline $8848 \mathrm{G}$ & & $3 \mathrm{Cu} 3$ & $105-107$ & & & 0.8 & 0.08 & 10 & 7.2 & & 6.6 & 23 & 6 & 17 \\
\hline $8848 \mathrm{H}$ & & $3 \mathrm{Cu} 4$ & 109-119 & & & \begin{tabular}{|l|}
1.2 \\
\end{tabular} & 0.05 & 24 & 7.2 & & 6.4 & 34 & 20 & 14 \\
\hline
\end{tabular}

\begin{tabular}{|c|c|c|c|c|c|c|c|c|c|c|}
\hline \multirow[b]{2}{*}{$\begin{array}{l}\text { S.B. } \\
\text { lab no. }\end{array}$} & \multirow[b]{2}{*}{$\begin{array}{c}\text { N.Z. } \\
\text { lab no. }\end{array}$} & \multirow[b]{2}{*}{$\begin{array}{c}\text { Horizon } \\
\text { desig. }\end{array}$} & \multirow[b]{2}{*}{$\begin{array}{c}\text { Sample } \\
\text { depth } \\
(\mathrm{cm})\end{array}$} & \multicolumn{6}{|c|}{ Physical-Mineralogical Properties } & \multirow[b]{2}{*}{ Comments } \\
\hline & & & & $\begin{array}{c}\text { Dry bulk } \\
\text { density } \\
t / m^{3}\end{array}$ & $\begin{array}{l}\text { Stones } \\
(\% \mathrm{v} / \mathrm{v})\end{array}$ & $\begin{array}{c}\% \text { Sand } \\
2.0-0.02 \\
\mathrm{~mm}\end{array}$ & $\begin{array}{c}\% \text { Silt } \\
0.02-0.002 \\
\mathrm{~mm}\end{array}$ & $\begin{array}{c}\% \text { Clay } \\
<0.002 \\
\mathrm{~mm}\end{array}$ & $\begin{array}{l}\text { Clay minerals } \\
\text { (topsoil only) }\end{array}$ & \\
\hline $8848 \mathrm{~A}$ & 5989 & Ap & $0-9$ & 0.89 & & 80 & 18 & 2 & \multirow{8}{*}{$\begin{array}{l}\text { Predomi- } \\
\text { nantly: Volca- } \\
\text { nic glass } \\
\text { (Allophane at } \\
\text { depth) } \\
\text { Small am'ts of: } \\
\text { smectite } \\
\text { and kaolin }\end{array}$} & \multirow{8}{*}{$\begin{array}{l}\Delta^{14} \mathrm{C} \text { and } \delta^{13} \mathrm{C} \text { analyses of soil } \\
\text { horizons are from a Tihoi Soil } \\
\text { at a nearby site under pasture, } \\
\text { altitude } 600 \mathrm{~m} \text {. Horizons, } \\
\text { depths corresponding to these C } \\
\text { isotope analyses: Ap 0-8 cm, } \\
\text { Bsh 8-27 cm, Bs } 27-44 \mathrm{~cm} \text {. } \\
\text { Blank spaces in tables indicate } \\
\text { no available data. } \\
\text { "C/N ratio not calculated where } \\
\mathrm{N}<0.05 \text {. } \\
\dagger \mathrm{CEC}=\text { cation exchange capac- } \\
\text { ity; me } \%=\mathrm{c} \mathrm{mol}(+) \mathrm{kg}^{-1}\end{array}$} \\
\hline 8848B & 5097 & $\mathrm{Ea}$ & $11-19$ & 0.72 & & 75 & 22 & 3 & & \\
\hline $8848 \mathrm{C}$ & $298 /$ & $\mathrm{Bh}$ & $21-37$ & 0.90 & & 89 & 7 & 4 & & \\
\hline $8848 \mathrm{D}$ & 5988 & Bs & $40-50$ & 1.17 & & 89 & 7 & 4 & & \\
\hline $8848 \mathrm{E}$ & & $2 \mathrm{Cu} 1$ & $52-78$ & 0.91 & & 93 & 6 & 1 & & \\
\hline $8848 \mathrm{~F}$ & & $3 \mathrm{Cu} 2$ & $80-105$ & & & 92 & 7 & 1 & & \\
\hline $8848 \mathrm{G}$ & & $3 \mathrm{Cu} 3$ & $105-107$ & & & 71 & 19 & 10 & & \\
\hline $8848 \mathrm{H}$ & & $3 \mathrm{Cu} 4$ & 109-119 & & & 73 & 16 & 11 & & \\
\hline
\end{tabular}


Site 3: Location and Soil Description

Soil name: Rotomahana Sandy Loam

Lab no. SB07672

Site, Soil Descriptions and Analytical Data

Date sampled: 22 Sept. 1960

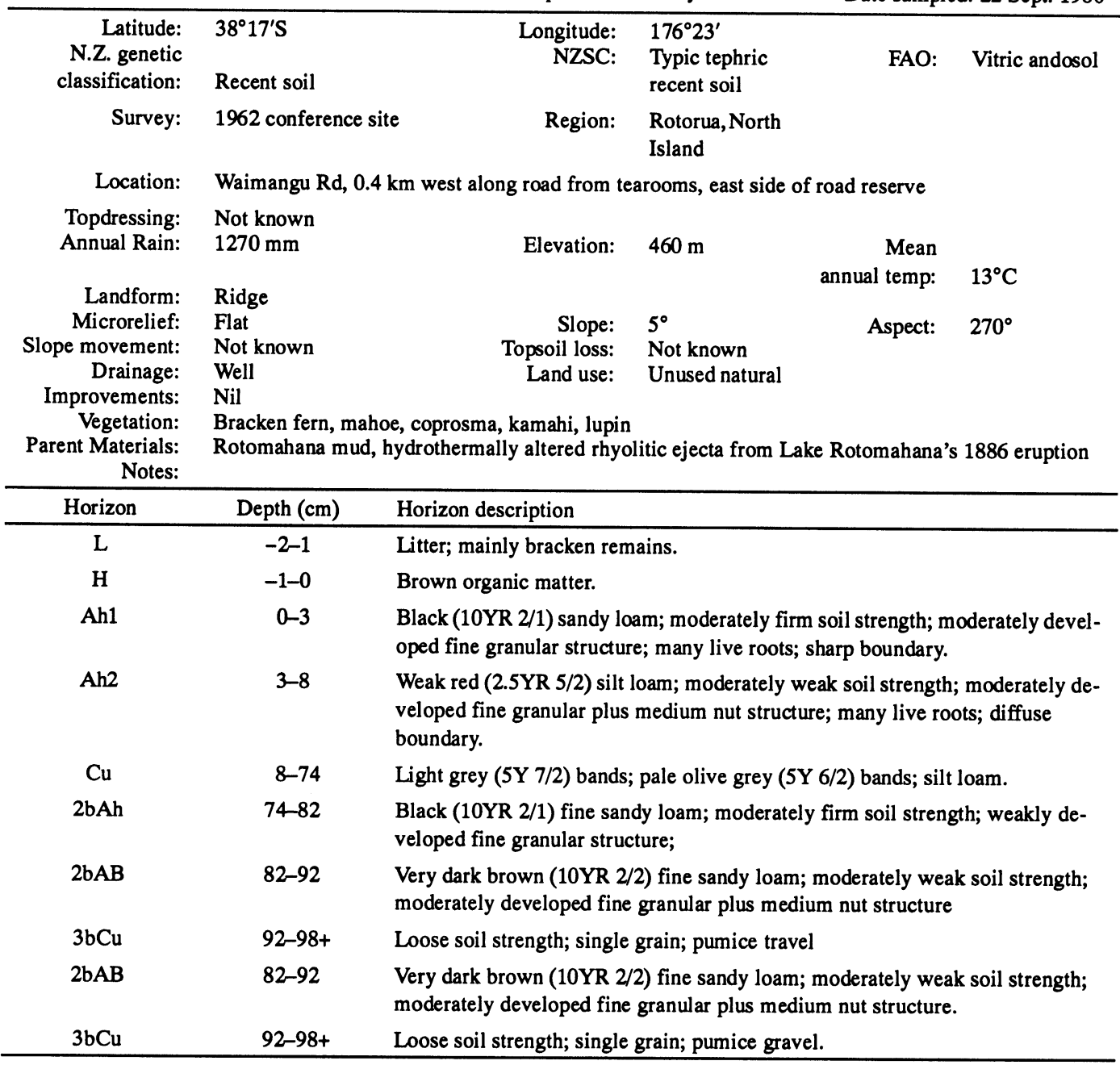

Site 3: Measurements

\begin{tabular}{|c|c|c|c|c|c|c|c|c|c|c|c|c|c|c|}
\hline \multirow{2}{*}{$\begin{array}{l}\text { S.B. } \\
\text { lab no. }\end{array}$} & \multirow{2}{*}{$\begin{array}{r}\text { N.Z. } \\
\text { lab no. }\end{array}$} & \multirow{2}{*}{$\begin{array}{c}\text { Horizon } \\
\text { desig. }\end{array}$} & \multirow{2}{*}{$\begin{array}{c}\text { Sample } \\
\text { depth } \\
(\mathrm{cm})\end{array}$} & \multicolumn{2}{|l|}{ Isotopes } & \multicolumn{9}{|c|}{ Chemical Properties } \\
\hline & & & & $\begin{array}{c}\Delta^{14} \mathrm{C} \\
\%_{00}\end{array}$ & $\begin{array}{l}\delta^{13} \mathrm{C} \\
\% 0\end{array}$ & $\begin{array}{l}\mathrm{C} \\
\%\end{array}$ & $\begin{array}{l}\mathbf{N} \\
\%\end{array}$ & $\mathrm{C} / \mathrm{N}$ & $\begin{array}{l}\text { CEC } \\
\text { me \% }\end{array}$ & $\begin{array}{c}\mathrm{pH}\left(\mathrm{H}_{2} \mathrm{O}\right) \\
\text { dry soil }\end{array}$ & $\begin{array}{l}\mathrm{pH}\left(\mathrm{H}_{2} \mathrm{O}\right) \\
\text { moist soil }\end{array}$ & \begin{tabular}{|c|} 
Total P \\
mg \%
\end{tabular} & $\begin{array}{l}\text { Org. P } \\
\text { mg \% }\end{array}$ & $\begin{array}{c}\text { Inorg. } P \\
\mathrm{mg} \%\end{array}$ \\
\hline & & $L$ & & & & & & & & & & & & \\
\hline & & $\mathrm{H}$ & & & & & & & & & & & & \\
\hline $7672 \mathrm{~A}$ & & Ah1 & $0-3$ & & & 9.9 & 0.54 & 18 & 32.8 & 5.7 & 5.8 & 67 & 36 & 31 \\
\hline 7672B & & Ah2 & $3-8$ & & & 1.3 & 0.07 & 19 & 11.3 & 5.5 & 5.8 & & & \\
\hline $7672 \mathrm{C}$ & 5729 & $\mathrm{Cu}$ & $30-61$ & $-436.9 \pm 13.9$ & -26.8 & 0.2 & 0.02 & $*$ & 14.0 & 6.2 & 6.4 & 29 & 0 & 29 \\
\hline 7672D & 5727 & $2 \mathrm{bAh}$ & 74-79 & $-33.8 \pm 3.8$ & -25.8 & 3.6 & 0.21 & 17 & 18.3 & 6.1 & 5.4 & & & \\
\hline $7672 \mathrm{E}$ & 5728 & $2 \mathrm{bAB}$ & $84-91$ & $-94.9 \pm 5.3$ & -24.8 & 3.4 & 0.14 & 24 & 12.9 & 6.2 & 5.5 & & & \\
\hline $7672 F$ & & $\mathrm{Ah}$ & $0-8$ & & & 1.9 & 0.12 & 16 & 11.1 & 5.7 & 5.9 & & & \\
\hline
\end{tabular}


Site 3: Measurements (Continued)

\begin{tabular}{|c|c|c|c|c|c|c|c|c|c|c|}
\hline \multirow[b]{2}{*}{$\begin{array}{l}\text { S.B. } \\
\text { lab no. }\end{array}$} & \multirow[b]{2}{*}{$\begin{array}{l}\text { N.Z. } \\
\text { lab no. }\end{array}$} & \multirow[b]{2}{*}{$\begin{array}{c}\text { Horizon } \\
\text { desig. }\end{array}$} & \multirow[b]{2}{*}{$\begin{array}{l}\text { Sample } \\
\text { depth } \\
\text { (cm) }\end{array}$} & \multicolumn{6}{|c|}{ Physical-Mineralogical Properties } & \multirow[b]{2}{*}{ Comments } \\
\hline & & & & $\begin{array}{c}\text { Dry bulk } \\
\text { density } \\
t / m^{3}\end{array}$ & $\begin{array}{l}\text { Stones } \\
(\% \mathrm{v} / \mathrm{v})\end{array}$ & $\begin{array}{c}\text { \% Sand } \\
2.0-0.02 \\
\mathrm{~mm}\end{array}$ & $\begin{array}{c}\% \text { Silt } \\
0.02-0.002 \\
\mathrm{~mm}\end{array}$ & $\begin{array}{c}\% \text { Clay } \\
<0.002 \\
\text { mm }\end{array}$ & $\begin{array}{l}\text { Clay minerals } \\
\text { (topsoil only) }\end{array}$ & \\
\hline & & $\bar{L}$ & & & & & & & \multirow{8}{*}{$\begin{array}{l}\text { Predominantly: } \\
\text { smectite } \\
\text { Small amounts } \\
\text { of: mica, allo- } \\
\text { phane, kaolin }\end{array}$} & \multirow{8}{*}{$\begin{array}{l}7672 \mathrm{~F} \text { was a bulk sample from } \\
2-10 \mathrm{~cm} \text { of the topsoil. Dry } \\
\text { bulk density figures for } \\
7672 \mathrm{~A}, \mathrm{~B} \text { were assumed from } \\
\text { the measured value for } 7672 \mathrm{~F} \text {. } \\
\text { Blank spaces in tables indicate } \\
\text { no available data. } \\
\text { *C/N ratio not calculated } \\
\text { where } \mathrm{N}<0.05 \text {. } \\
+\mathrm{CEC}=\mathrm{cation} \text { exchange ca- } \\
\text { pacity; me } \%=\mathrm{cmol}(+) \mathrm{kg}\end{array}$} \\
\hline & & $\overline{\mathrm{H}}$ & & & & & & & & \\
\hline $7672 A$ & & Ah1 & $0-3$ & 0.69 & & 61 & 25 & 12 & & \\
\hline $7672 B$ & & Ah2 & $3-8$ & 0.69 & & & & & & \\
\hline $7672 \mathrm{C}$ & 5729 & $\mathrm{Cu}$ & $30-61$ & 1.20 & & 50 & 36 & 13 & & \\
\hline $7672 \mathrm{D}$ & 5727 & $2 \mathrm{bAh}$ & $74-79$ & 0.69 & & & & & & \\
\hline $7672 \mathrm{E}$ & 5728 & $2 \mathrm{bAB}$ & $84-91$ & & & & & & & \\
\hline $7672 \mathrm{~F}$ & & $\mathrm{Ah}$ & $0-8$ & 0.69 & & & & & & \\
\hline
\end{tabular}

\section{Site 5: Location and Soil Description}

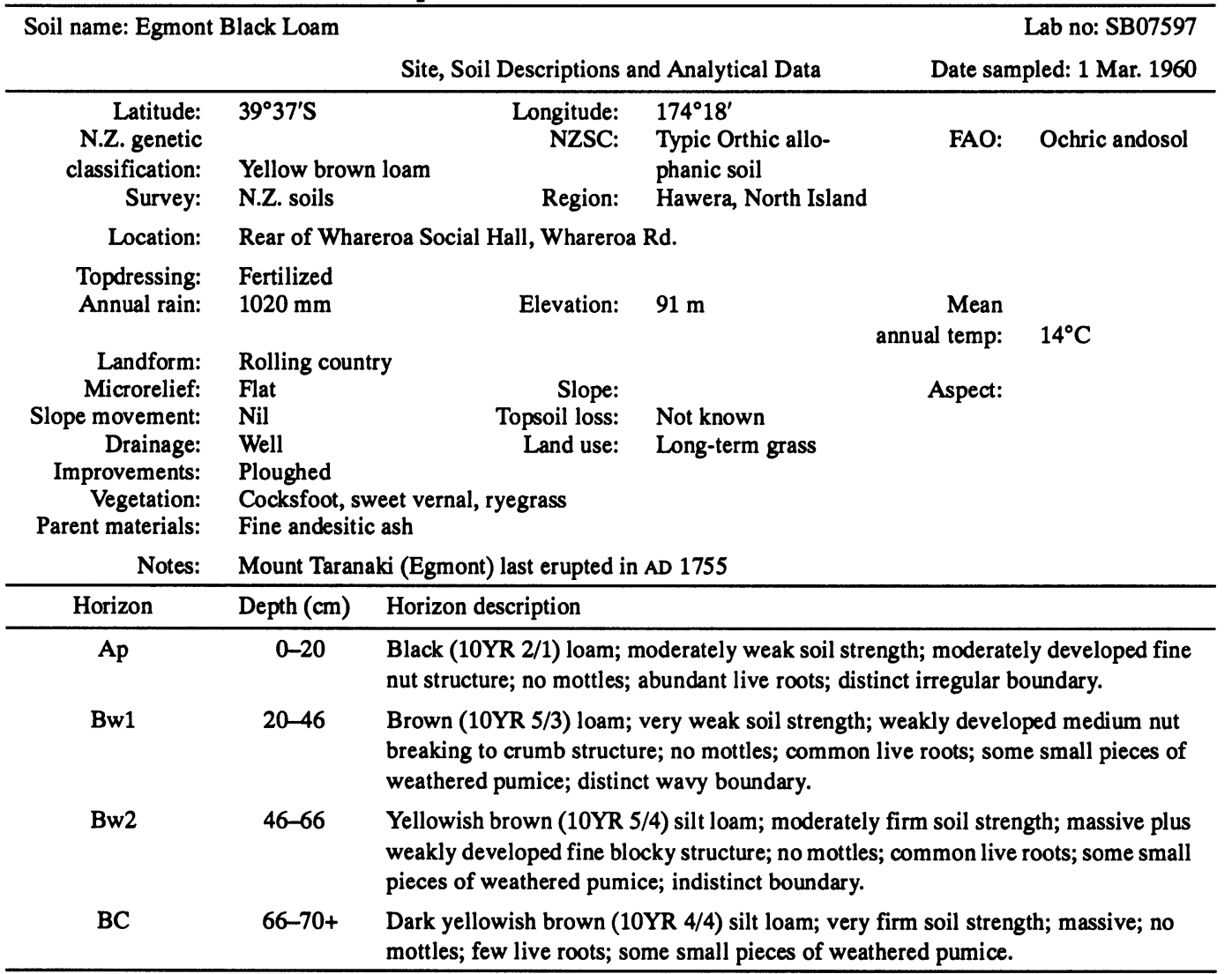

\section{Site 5: Measurements}

\begin{tabular}{|c|c|c|c|c|c|c|c|c|c|c|c|c|c|c|}
\hline \multirow{2}{*}{$\begin{array}{l}\text { S.B. } \\
\text { lab no. }\end{array}$} & \multirow{2}{*}{$\begin{array}{r}\text { N.Z. } \\
\text { lab no. }\end{array}$} & \multirow{2}{*}{$\begin{array}{c}\text { Horizon } \\
\text { desig. }\end{array}$} & \multirow{2}{*}{$\begin{array}{c}\text { Sample } \\
\text { depth } \\
\text { (cm) }\end{array}$} & \multicolumn{2}{|c|}{ Isotopes } & \multicolumn{9}{|c|}{ Chemical Properties } \\
\hline & & & & $\begin{array}{c}\Delta^{14} \mathrm{C} \\
9_{00}\end{array}$ & $\begin{array}{c}\delta^{13} \mathrm{C} \\
\%_{00}\end{array}$ & $\begin{array}{l}\mathrm{C} \\
\%\end{array}$ & $\begin{array}{l}\mathrm{N} \\
\%\end{array}$ & $\mathrm{C} / \mathrm{N}$ & $\begin{array}{l}\text { CECt } \\
\text { me \% }\end{array}$ & $\begin{array}{c}\mathrm{pH}\left(\mathrm{H}_{2} \mathrm{O}\right) \\
\text { dry soil }\end{array}$ & $\begin{array}{l}\mathrm{pH}\left(\mathrm{H}_{2} \mathrm{O}\right) \\
\text { moist soil }\end{array}$ & $\begin{array}{c}\text { Total P } \\
\text { mg \% }\end{array}$ & $\begin{array}{l}\text { Org. P } \\
\text { mg \% }\end{array}$ & $\begin{array}{c}\text { Inorg. P } \\
\text { mg \% }\end{array}$ \\
\hline $7597 \mathrm{~A}$ & & $\overline{\mathrm{Ap}}$ & $0-8$ & & & 12.3 & 0.93 & 13 & 36.9 & 5.7 & 6.0 & 256 & 136 & 120 \\
\hline 7597B & 2345 & Ap & $8-15$ & $43.2 \pm 7.3$ & -26.2 & 8.7 & 0.71 & 12 & 31.2 & 6.2 & 6.0 & 238 & 125 & 113 \\
\hline 7597C & 2346 & Bw1 & $20-36$ & $-97.5 \pm 4.5$ & -24.7 & 3.6 & 0.40 & 9 & 19.1 & 6.3 & 6.4 & 248 & 107 & 141 \\
\hline $7597 \mathrm{D}$ & 2347 & Bw2 & $46-56$ & $-176.5 \pm 6.4$ & -25.5 & 1.7 & 0.20 & 9 & 13.2 & $\overline{6.4}$ & $\overline{6.4}$ & 167 & 57 & 110 \\
\hline $7597 \mathrm{E}$ & 2348 & $\overline{\mathrm{BC}}$ & $74-89$ & $-457.5 \pm 5.9$ & -25.0 & 1.1 & 0.15 & $\overline{7}$ & 14.2 & $\overline{6.4}$ & $\overline{6.4}$ & 127 & 50 & 77 \\
\hline
\end{tabular}


Site 5: Measurements (Continued)

\begin{tabular}{|c|c|c|c|c|c|c|c|c|c|c|}
\hline \multirow[b]{2}{*}{$\begin{array}{c}\text { S.B. } \\
\text { lab no. }\end{array}$} & \multirow[b]{2}{*}{$\begin{array}{c}\text { N.Z. } \\
\text { lab no. }\end{array}$} & \multirow[b]{2}{*}{$\begin{array}{c}\text { Horizon } \\
\text { desig. }\end{array}$} & \multirow[b]{2}{*}{$\begin{array}{c}\text { Sample } \\
\text { depth } \\
\text { (cm) }\end{array}$} & \multicolumn{6}{|c|}{ Physical-Mineralogical Properties } & \multirow[b]{2}{*}{ Comments } \\
\hline & & & & $\mid \begin{array}{c}\text { Dry bulk } \\
\text { density } \\
t / m^{3}\end{array}$ & $\begin{array}{l}\text { Stones } \\
(\% \mathrm{v} / \mathrm{v})\end{array}$ & $\begin{array}{c}\% \text { Sand } \\
2.0-0.02 \\
\mathrm{~mm}\end{array}$ & $\begin{array}{c}\% \text { Silt } \\
0.02-0.002 \\
\mathrm{~mm}\end{array}$ & $\begin{array}{c}\% \text { Clay } \\
<0.002 \\
\text { mm }\end{array}$ & $\begin{array}{l}\text { Clay minerals } \\
\text { (topsoil only) }\end{array}$ & \\
\hline $7597 \mathrm{~A}$ & & Ap & $0-8$ & 0.66 & & 55 & 23 & 22 & \multirow{5}{*}{$\begin{array}{l}\text { Predominantly: Al- } \\
\text { lophane, volcanic } \\
\text { glass, HIV } \\
\text { Small amounts of: } \\
\text { halloysite }\end{array}$} & \multirow{5}{*}{$\begin{array}{l}\text { Blank spaces in tables } \\
\text { indicate no available } \\
\text { data. } \\
\text { †CEC = cation ex- } \\
\text { change capacity; me \% } \\
=\text { c mol }(+) \mathrm{kg}^{-1}\end{array}$} \\
\hline 7597B & 2345 & Ap & $8-15$ & 0.82 & & 56 & 26 & 18 & & \\
\hline \begin{tabular}{|l|}
$7597 C$ \\
\end{tabular} & 2346 & Bw1 & $20-36$ & 0.74 & & 65 & 26 & 9 & & \\
\hline $7597 \mathrm{D}$ & 2347 & $\mathrm{Bw} 2$ & $46-56$ & 0.83 & & 67 & 21 & 12 & & \\
\hline $7597 \mathrm{E}$ & 2348 & $\mathrm{BC}$ & $74-89$ & 0.85 & & & & & & \\
\hline
\end{tabular}

\section{Site 10: Location and Soil Description}

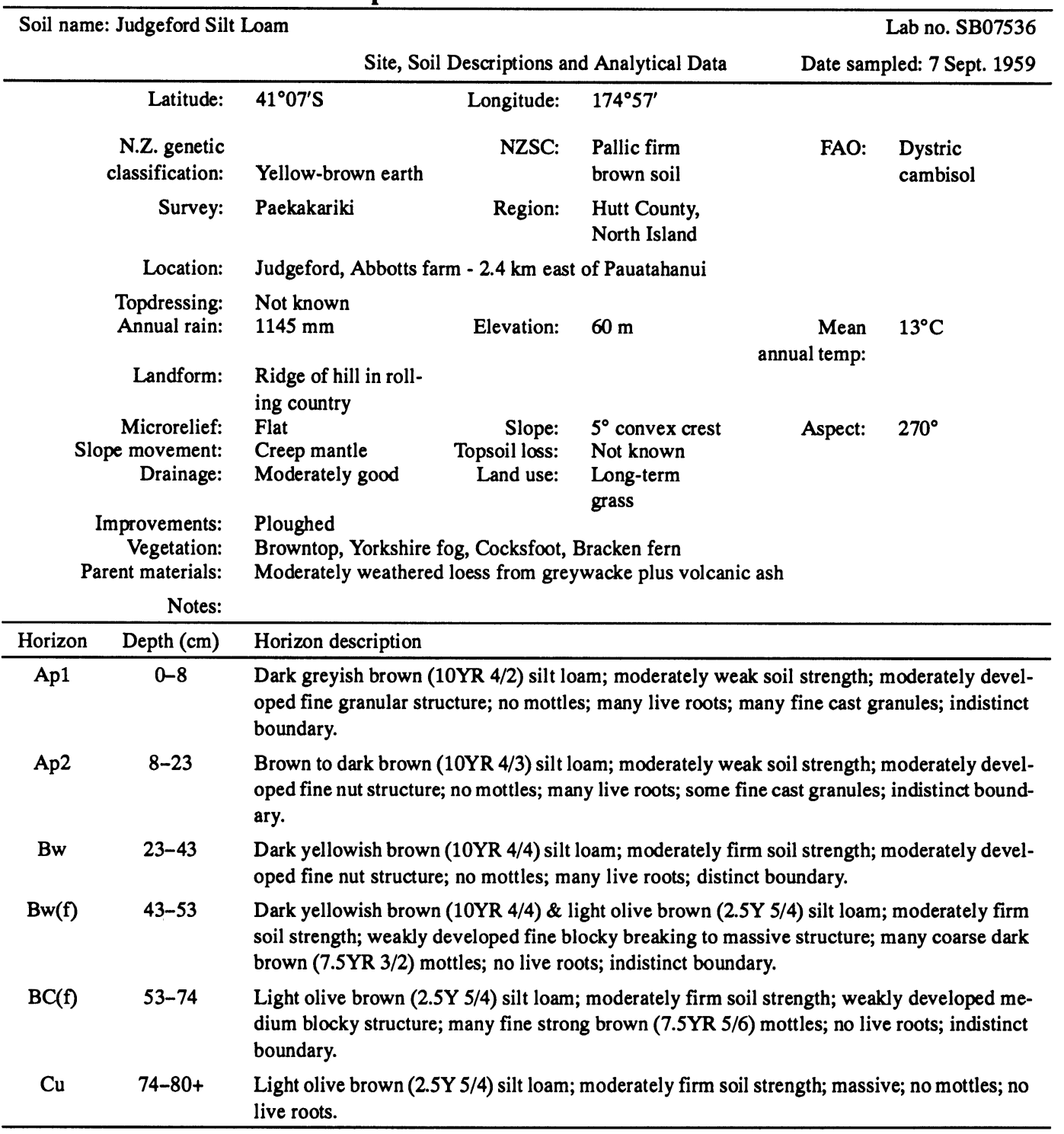


Site 10: Measurements

\begin{tabular}{|c|c|c|c|c|c|c|c|c|c|c|c|c|c|c|}
\hline \multirow{2}{*}{$\begin{array}{l}\text { S.B. } \\
\text { lab no. }\end{array}$} & \multirow{2}{*}{$\begin{array}{c}\text { N.Z. } \\
\text { lab no. }\end{array}$} & \multirow{2}{*}{$\begin{array}{l}\text { Horizon } \\
\text { desig. }\end{array}$} & \multirow{2}{*}{$\begin{array}{c}\text { Sample } \\
\text { depth } \\
\text { (cm) }\end{array}$} & \multicolumn{2}{|c|}{ Isotopes } & \multicolumn{9}{|c|}{ Chemical Properties } \\
\hline & & & & $\begin{array}{c}\Delta^{14} \mathrm{C} \\
\%_{00}\end{array}$ & $\begin{array}{c}\delta^{13} \mathrm{C} \\
\%_{0}\end{array}$ & $\begin{array}{l}\mathrm{C} \\
\%\end{array}$ & $\begin{array}{l}\mathrm{N} \\
\%\end{array}$ & $\mathrm{C} / \mathrm{N}$ & $\begin{array}{l}\text { CEC* } \\
\text { me \% }\end{array}$ & $\begin{array}{c}\mathrm{pH}\left(\mathrm{H}_{2} \mathrm{O}\right) \\
\text { dry soil }\end{array}$ & $\begin{array}{l}\mathrm{pH}\left(\mathrm{H}_{2} \mathrm{O}\right) \\
\text { moist soil }\end{array}$ & $\begin{array}{c}\text { Total P } \\
\mathrm{mg} \%\end{array}$ & $\begin{array}{l}\text { Org. P } \\
\mathrm{mg} \%\end{array}$ & $\begin{array}{c}\text { Inorg. } P \\
\mathrm{mg} \%\end{array}$ \\
\hline $7536 \mathrm{~A}$ & 2352 & Ap1 & $0-8$ & $-34.9 \pm 6.8$ & \begin{tabular}{|l|}
-27.5 \\
\end{tabular} & 7.1 & 0.48 & 15 & 19.9 & 4.5 & 5.9 & 49 & 36 & 13 \\
\hline 7536B & 2353 & Ap2 & $8-20$ & $-44.0 \pm 6.8$ & -27.1 & 4.2 & 0.31 & 14 & 15.5 & 5.4 & 5.9 & 35 & 22 & 13 \\
\hline $7536 \mathrm{C}$ & 2354 & $\mathrm{Bw}$ & $25-43$ & $-140.2 \pm 6.4$ & -26.0 & 1.9 & 0.12 & 16 & 10.5 & 5.4 & 5.9 & 24 & 13 & 11 \\
\hline $7536 \mathrm{D}$ & 2355 & $\mathrm{Bw}(\mathrm{f})$ & $46-53$ & $-350.0 \pm 6.6$ & -26.1 & 1.0 & 0.08 & 13 & 8.5 & 5.6 & 5.9 & 28 & $\overline{16}$ & 12 \\
\hline $7536 \mathrm{E}$ & 2356 & $\mathrm{BC}(\mathrm{f})$ & 58-74 & $-457.1 \pm 6.1$ & -24.9 & 0.7 & 0.07 & 10 & 9.4 & 5.5 & 5.6 & 33 & 18 & 15 \\
\hline $7536 \mathrm{~F}$ & & $\mathrm{Cu}$ & $76-94$ & & & 0.7 & 0.06 & 12 & 6.0 & 5.3 & 5.8 & 45 & 23 & 22 \\
\hline
\end{tabular}

\begin{tabular}{|c|c|c|c|c|c|c|c|c|c|c|}
\hline \multirow[b]{2}{*}{$\begin{array}{c}\text { S.B. } \\
\text { lab no. }\end{array}$} & \multirow[b]{2}{*}{$\begin{array}{l}\text { N.Z. } \\
\text { lab no. }\end{array}$} & \multirow[b]{2}{*}{$\begin{array}{l}\text { Horizon } \\
\text { desig. }\end{array}$} & \multirow[b]{2}{*}{$\begin{array}{c}\text { Sample } \\
\text { depth } \\
(\mathrm{cm})\end{array}$} & \multicolumn{6}{|c|}{ Physical-Mineralogical Properties } & \multirow[b]{2}{*}{ Comments } \\
\hline & & & & $\begin{array}{c}\text { Dry bulk } \\
\text { density } \\
t / \mathrm{m}^{3}\end{array}$ & $\begin{array}{l}\text { Stones } \\
(\% \mathrm{v} / \mathrm{v})\end{array}$ & $\begin{array}{c}\text { \% Sand } \\
2.0-0.02 \\
\text { MM }\end{array}$ & $\begin{array}{c}\% \text { Silt } \\
0.02-0.002 \\
\text { MM }\end{array}$ & $\begin{array}{c}\% \text { Clay } \\
<0.002 \mathrm{~mm}\end{array}$ & $\begin{array}{l}\text { Clay minerals } \\
\text { (topsoil only) }\end{array}$ & \\
\hline 7536A & 2352 & Ap1 & $0-8$ & 0.94 & & 31 & 33 & 23 & \multirow{6}{*}{$\begin{array}{l}\text { Predominantly: } \\
\text { vermiculite } \\
\text { Small amounts of: } \\
\text { mica-vermiculite }\end{array}$} & \multirow{6}{*}{$\begin{array}{l}\text { Blank spaces in ta- } \\
\text { bles indicate no } \\
\text { available data. } \\
{ }^{*} \text { CEC = cation ex- } \\
\text { change capacity; me } \\
\%=\text { c mol }(+) \mathrm{kg}^{-1}\end{array}$} \\
\hline 7536B & 2353 & Ap2 & $8-20$ & 1.05 & & 32 & 36 & 32 & & \\
\hline $7536 \mathrm{C}$ & 2354 & $\mathrm{Bw}$ & $25-43$ & 1.31 & & 39 & 33 & 22 & & \\
\hline 7536D & 2355 & $\mathrm{Bw}(\mathrm{f})$ & $46-53$ & 1.38 & & 41 & 32 & 27 & & \\
\hline $7536 \mathrm{E}$ & 2356 & $\mathrm{BC}(\mathrm{f})$ & $58-74$ & 1.42 & & 39 & 34 & 27 & & \\
\hline $7536 \mathrm{~F}$ & & $\mathrm{Cu}$ & $76-94$ & & & & & & & \\
\hline
\end{tabular}

\section{Site 13: Location and Soil Description}

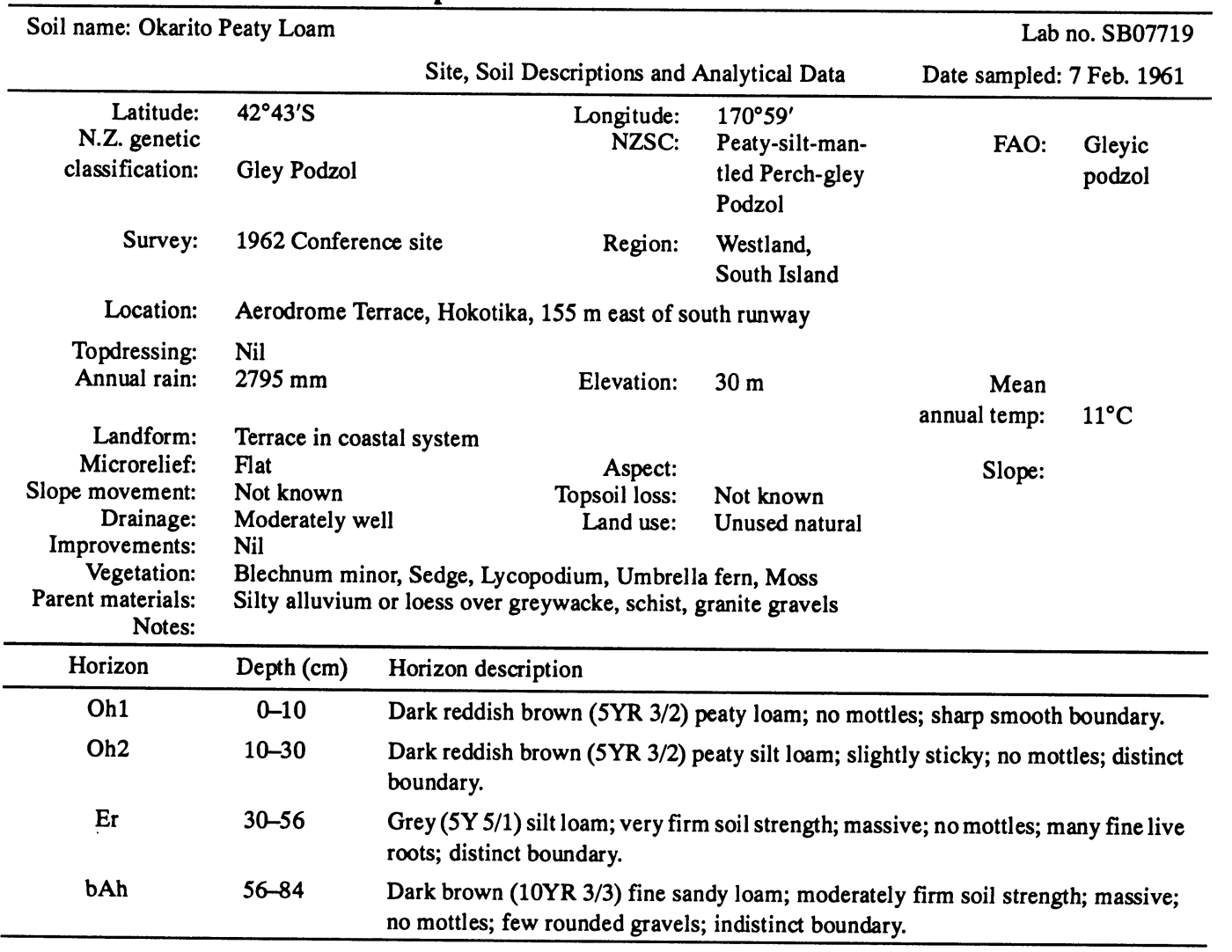


Site 13: Location and Soil Description (Continued)

\begin{tabular}{ccl}
\hline bEr1 & $84-97$ & $\begin{array}{l}\text { Weak red (2.5YR 4/2) loamy very fine sand; very firm soil strength; massive; no } \\
\text { mottles; indistinct boundary. }\end{array}$ \\
bEr2 & $97-102$ & $\begin{array}{l}\text { Grey (5Y 5/1) loamy very fine sand; moderately firm soil strength; massive; no } \\
\text { mottles; indistinct boundary. }\end{array}$ \\
$2 \mathrm{bBh}$ & $102-112$ & $\begin{array}{l}\text { Dark brown (10YR 3/3) gravelly sand; loose soil strength; no mottles; many } \\
\text { strongly weathered subangular stones. } \\
\text { Dark reddish brown (2.5YR 3/4) strongly cemented; no mottles; continuous iron- } \\
\text { pan; sandwiching loose gravelly sand. single grain; no mottles; many stones. }\end{array}$ \\
$3 \mathrm{bBfm} / \mathrm{Cu}$ & $112-127$ & Gravelly sand; loose soil strength; single grain; no mottles; many stones.
\end{tabular}

\section{Site 13: Measurements}

\begin{tabular}{|c|c|c|c|c|c|c|c|c|c|c|c|c|c|c|}
\hline \multirow{2}{*}{$\begin{array}{c}\text { S.B. } \\
\text { lab no. }\end{array}$} & \multirow{2}{*}{$\begin{array}{l}\text { N.Z. } \\
\text { lab no. }\end{array}$} & \multirow{2}{*}{$\begin{array}{c}\text { Horizon } \\
\text { desig. }\end{array}$} & \multirow{2}{*}{$\begin{array}{c}\text { Sample } \\
\text { depth } \\
(\mathrm{cm})\end{array}$} & \multicolumn{2}{|c|}{ Isotopes } & \multicolumn{9}{|c|}{ Chemical Properties } \\
\hline & & & & $\begin{array}{l}\Delta^{14} \mathrm{C} \\
\% 0\end{array}$ & $\begin{array}{c}\delta^{13} \mathrm{C} \\
\%_{00}\end{array}$ & $\begin{array}{l}\mathrm{C} \\
\%\end{array}$ & $\begin{array}{l}\mathrm{N} \\
\%\end{array}$ & $\mathrm{C} / \mathrm{N}$ & \begin{tabular}{|l|} 
CEC \\
me \%
\end{tabular} & \begin{tabular}{|c|}
$\mathrm{pH}\left(\mathrm{H}_{2} \mathrm{O}\right)$ \\
dry soil
\end{tabular} & $\begin{array}{l}\mathrm{pH}\left(\mathrm{H}_{2} \mathrm{O}\right) \\
\text { moist soil }\end{array}$ & $\begin{array}{l}\text { Total P } \\
\text { mg \% }\end{array}$ & $\begin{array}{l}\text { Org. P } \\
\text { mg \% }\end{array}$ & $\begin{array}{c}\text { Inorg. P } \\
\text { mg \% }\end{array}$ \\
\hline $7719 A$ & & Oh1 & $0-8$ & & & 30.8 & 1.28 & 24 & 66.4 & 4.1 & 4.4 & 58 & 47 & 11 \\
\hline $719 \mathrm{~B}$ & 2361 & Oh2 & $13-30$ & $-24.7 \pm 6.9$ & -27.6 & 19.7 & 0.59 & 33 & 30.8 & 4.1 & 4.7 & 21 & 10 & 11 \\
\hline $7719 \mathrm{C}$ & 2362 & Er & $33-48$ & $-317.0 \pm 5.9$ & -27.9 & 5.2 & 0.12 & 43 & 15.3 & 4.7 & 5.1 & 14 & 7 & 7 \\
\hline $7719 \mathrm{D}$ & 2363 & bAh & $56-84$ & $-646.6 \pm 3.9$ & -28.0 & 8.9 & 0.19 & 47 & 27.5 & 4.9 & 4.9 & 36 & 30 & 6 \\
\hline $7719 \mathrm{E}$ & 2364 & $\mathrm{bEr}$ & 84-97 & $-667.8 \pm 4.7$ & -29.2 & 4.3 & 0.13 & 33 & 15.6 & 4.8 & 4.8 & 24 & 18 & 6 \\
\hline $719 \mathrm{~F}$ & 2365 & $2 \mathrm{bBh}$ & $102-112$ & $-442.4 \pm 5.4$ & -27.8 & 4.0 & 0.09 & 44 & 21.2 & 4.8 & 5.0 & 38 & 9 & 29 \\
\hline
\end{tabular}

\begin{tabular}{|c|c|c|c|c|c|c|c|c|c|c|}
\hline \multirow[b]{2}{*}{$\begin{array}{l}\text { S.B. } \\
\text { lab no. }\end{array}$} & \multirow[b]{2}{*}{$\begin{array}{l}\text { N.Z. } \\
\text { lab no. }\end{array}$} & \multirow[b]{2}{*}{$\begin{array}{c}\text { Horizon } \\
\text { desig. }\end{array}$} & \multirow[b]{2}{*}{$\begin{array}{l}\text { Sample } \\
\text { depth } \\
(\mathrm{cm})\end{array}$} & \multicolumn{6}{|c|}{ Physical-Mineralogical Properties } & \multirow[b]{2}{*}{ Comments } \\
\hline & & & & $\begin{array}{c}\text { Dry bulk } \\
\text { density } \\
t / m^{3}\end{array}$ & $\begin{array}{l}\text { Stones } \\
(\% \mathrm{v} / \mathrm{v})\end{array}$ & $\begin{array}{c}\text { \% Sand } \\
2.0-0.02 \\
\mathrm{~mm}\end{array}$ & $\begin{array}{c}\% \text { Silt } \\
0.02-0.002 \\
\mathrm{~mm}\end{array}$ & $\begin{array}{c}\% \text { Clay } \\
<0.002 \\
\mathrm{~mm}\end{array}$ & $\begin{array}{l}\text { Clay minerals } \\
\text { (topsoil only) }\end{array}$ & \\
\hline 7719A & & Oh1 & $0-8$ & 0.38 & & & & & \multirow{6}{*}{$\begin{array}{l}\text { Predominantly: } \\
\text { quartz, mica } \\
\text { Small amounts } \\
\text { of: mica-vermic } \\
\text { ulite, vermicu- } \\
\text { lite, kaolin }\end{array}$} & \multirow{6}{*}{$\begin{array}{l}\text { Dry bulk density figures for } \\
7719 \mathrm{~A}, \mathrm{~B} \text { were estimated } \\
\text { from } 12 \text { Oh horizons with } \\
\text { similar carbon contents at } \\
\text { similar depths. } \\
\text { Mean }=0.38 \mathrm{Std} \text { Dev }=0.17 \\
\text { Blank spaces in tables indi- } \\
\text { cate no available data. } \\
\text { "CEC }=\text { cation exchange ca- }^{\text {"C }} \text { pacity; me \% }=\mathrm{cmol}(+) \mathrm{kg}^{-1}\end{array}$} \\
\hline 7719B & 2361 & Oh2 & $13-30$ & 0.38 & & 49 & 43 & 8 & & \\
\hline 7719C & 2362 & $\mathrm{Er}$ & $33-48$ & 0.91 & & 56 & 34 & 10 & & \\
\hline 7719D & 2363 & bAh & $56-84$ & 0.76 & & 60 & 28 & 12 & & \\
\hline $7719 \mathrm{E}$ & 2364 & bEr & 84-97 & 1.03 & & 63 & 31 & 6 & & \\
\hline $7719 \mathrm{~F}$ & 2365 & $2 \mathrm{bBh}$ & $102-112$ & & 20 & 80 & 15 & 5 & & \\
\hline
\end{tabular}

\section{Site 16: Location and Soil Description}

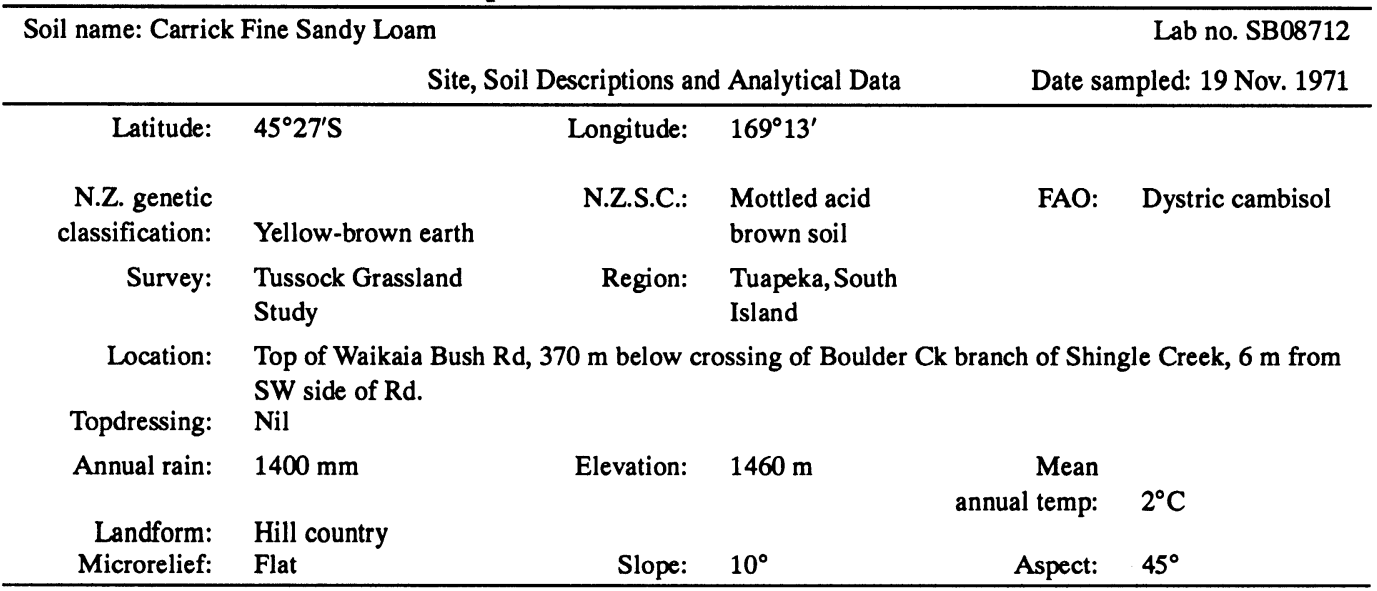


Site 16: Location and Soil Description (Continued)

\begin{tabular}{|c|c|c|}
\hline $\begin{array}{r}\text { Slope move- } \\
\text { ment: } \\
\text { Drainage: } \\
\text { Improvements: } \\
\text { Vegetation: } \\
\text { Parent materials: } \\
\text { Notes: }\end{array}$ & \multicolumn{2}{|c|}{$\begin{array}{l}\text { Chionochloa rigida and macra, Poa colensoi, Open tussock } \\
\text { Moderately weathered Schist } \\
\text { A ? on the "Soil Name" indicates the series name for this profile is tentative, however, all other data } \\
\text { is considered to be valid. Hor } 310 \text { YR } 4 / 3 \text {. Hor } 45 \text { Y } 5 / 2-6 / 2 \text { (Gley areas) }\end{array}$} \\
\hline Horizon & Depth (cm) & Horizon description \\
\hline Ah1 & $0-1$ & $\begin{array}{l}\text { Very dark greyish brown (10YR } 3 / 2) \text { silt loam; moderately developed crumb struc- } \\
\text { ture; abundant live roots; distinct boundary. }\end{array}$ \\
\hline Ah2 & $1-4$ & $\begin{array}{l}\text { Brown to dark brown (10YR 4/3) silt loam; moderately developed crumb structure; } \\
\text { many live roots; indistinct boundary. }\end{array}$ \\
\hline $\mathrm{Bw}$ & $4-9$ & $\begin{array}{l}\text { Yellowish brown (10YR 5/4) silt loam; weakly developed nut plus moderately de- } \\
\text { veloped crumb structure; few stones; few live roots; distinct boundary. }\end{array}$ \\
\hline$B w(f)$ & $9-20$ & $\begin{array}{l}\text { Light olive brown ( } 2.5 \text { Y } 5 / 4) \text { silt loam; weakly developed medium nut structure; } \\
\text { faint strong brown ( } 7.5 \text { YR } 5 / 6 \text { ) mottles; weakly weathered schist stones; indistinct } \\
\text { boundary. }\end{array}$ \\
\hline BC & $20-36$ & $\begin{array}{l}\text { Light olive brown (2.5Y 5/4) fine sandy loam; weakly developed blocky structure; } \\
\text { yellowish brown (10YR 5/6) coatings; abundant stones. }\end{array}$ \\
\hline
\end{tabular}

\section{Site 16: Measurements}

\begin{tabular}{|c|c|c|c|c|c|c|c|c|c|c|c|c|c|c|}
\hline \multirow{2}{*}{$\begin{array}{l}\text { S.B. } \\
\text { lab no. }\end{array}$} & \multirow{2}{*}{$\begin{array}{l}\text { N.Z. } \\
\text { lab no. }\end{array}$} & \multirow{2}{*}{$\begin{array}{c}\text { Horizon } \\
\text { desig. }\end{array}$} & \multirow{2}{*}{$\begin{array}{c}\text { Sample } \\
\text { depth } \\
(\mathrm{cm})\end{array}$} & \multicolumn{2}{|c|}{ Isotopes } & \multicolumn{9}{|c|}{ Chemical Properties } \\
\hline & & & & $\begin{array}{c}\Delta^{14} \mathrm{C} \\
\%_{00}\end{array}$ & $\begin{array}{c}\delta^{13} \mathrm{C} \\
\%_{00}\end{array}$ & $\begin{array}{l}\mathrm{C} \\
\%\end{array}$ & $\begin{array}{l}\mathbf{N} \\
\%\end{array}$ & $\mathrm{C} / \mathrm{N}$ & $\begin{array}{l}\text { CEC* } \\
\text { me \% }\end{array}$ & $\begin{array}{c}\mathrm{pH}\left(\mathrm{H}_{2} \mathrm{O}\right) \\
\text { dry soil }\end{array}$ & $\begin{array}{l}\mathrm{pH}\left(\mathrm{H}_{2} \mathrm{O}\right) \\
\text { moist soil }\end{array}$ & $\begin{array}{l}\text { Total P } \\
\text { mg \% }\end{array}$ & $\begin{array}{l}\text { Org. P } \\
\text { mg \% }\end{array}$ & $\begin{array}{c}\text { Inorg. } \mathrm{P} \\
\mathrm{mg} \%\end{array}$ \\
\hline & & Ah1 & $0-1$ & & & & & & & & & & & \\
\hline $8712 \mathrm{~A}$ & 4570 & Ah2 & $1-4$ & $85.0 \pm 8.6$ & -25.7 & 4.9 & 0.32 & 15 & 19.5 & & 4.6 & 88 & 65 & 23 \\
\hline 8712B & 4571 & Bw & $4-9$ & $-16.8 \pm 3.9$ & $\mid-25.8$ & 3.7 & 0.21 & 18 & 18.8 & & 4.6 & 71 & 52 & 19 \\
\hline $8712 \mathrm{C}$ & 4572 & $B w(f)$ & $9-20$ & $-79.2 \pm 3.8$ & -25.8 & 2.9 & 0.19 & 15 & 18.1 & & 4.7 & 61 & 45 & 16 \\
\hline 8712D & 4573 & BC & $20-36$ & $-117.2 \pm 3.7$ & -25.9 & 2.3 & 0.16 & 14 & 17.5 & & 4.8 & 57 & 44 & 13 \\
\hline
\end{tabular}

\begin{tabular}{|c|c|c|c|c|c|c|c|c|c|c|}
\hline \multirow[b]{2}{*}{$\begin{array}{c}\text { S.B. } \\
\text { lab no. }\end{array}$} & \multirow[b]{2}{*}{$\begin{array}{l}\text { N.Z. } \\
\text { lab no. }\end{array}$} & \multirow[b]{2}{*}{$\begin{array}{l}\text { Horizon } \\
\text { desig. }\end{array}$} & \multirow[b]{2}{*}{$\begin{array}{c}\text { Sample } \\
\text { depth } \\
(\mathrm{cm})\end{array}$} & \multicolumn{6}{|c|}{ Physical-Mineralogical Properties } & \multirow[b]{2}{*}{ Comments } \\
\hline & & & & $\begin{array}{c}\text { Dry bulk } \\
\text { density } \\
\left(t / m^{3}\right)\end{array}$ & $\begin{array}{l}\text { Stones } \\
(\% \mathrm{v} / \mathrm{v})\end{array}$ & $\begin{array}{c}\text { \% Sand } \\
2.0-0.02 \\
(\mathrm{~mm})\end{array}$ & $\begin{array}{c}\% \text { Silt } \\
0.02-0.002 \\
(\mathrm{~mm})\end{array}$ & $\begin{array}{l}\% \text { Clay } \\
<0.002 \\
(\mathrm{~mm})\end{array}$ & $\begin{array}{l}\text { Clay minerals } \\
\text { (topsoil only) }\end{array}$ & \\
\hline & & Ah1 & $0-1$ & & & & & & \multirow{5}{*}{$\begin{array}{l}\text { Predominantly: } \\
\text { mica-vermicu- } \\
\text { lite }\end{array}$} & \multirow{5}{*}{$\begin{array}{l}\text { Blank spaces in ta- } \\
\text { bles indicate no } \\
\text { available data. } \\
{ }^{*} \mathrm{CEC}=\text { cation ex- } \\
\text { change capacity; me } \\
\%=\mathrm{c} \mathrm{mol}(+) \mathrm{kg}^{-1}\end{array}$} \\
\hline $8712 \mathrm{~A}$ & 4570 & Ah2 & $1-4$ & 0.79 & & & & & & \\
\hline 8712B & 4571 & Bw & 4-9 & 0.88 & & & & & & \\
\hline $8712 \mathrm{C}$ & 4572 & $\mathrm{Bw}(\mathrm{f})$ & $9-20$ & 1.03 & & & & & & \\
\hline 8712D & 4573 & BC & $20-36$ & 1.19 & & & & & & \\
\hline
\end{tabular}


Site 19: Location and Soil Description

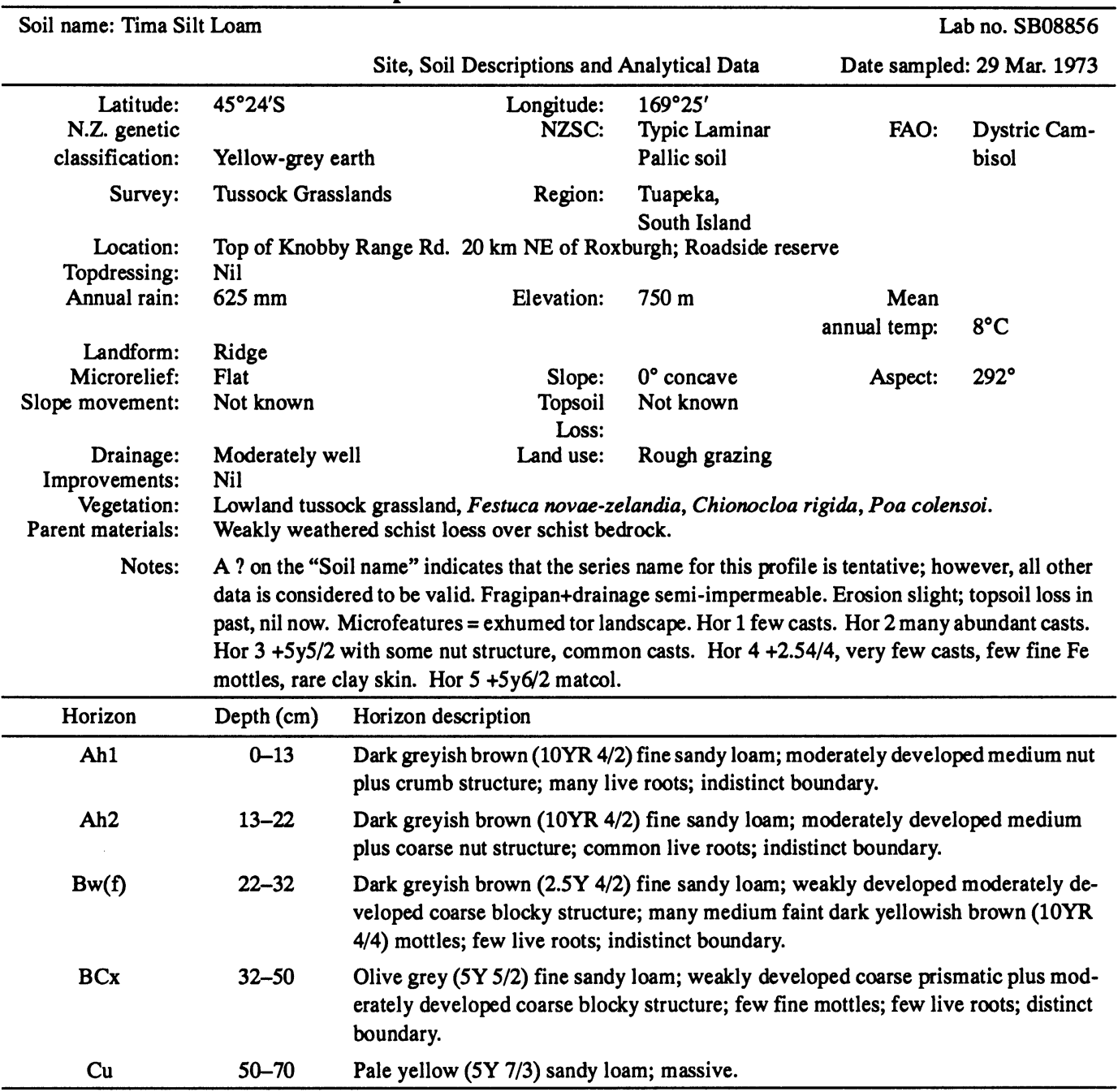

\section{Site 19: Measurements}

\begin{tabular}{|c|c|c|c|c|c|c|c|c|c|c|c|c|c|c|}
\hline \multirow{2}{*}{$\begin{array}{l}\text { S.B. } \\
\text { lab no. }\end{array}$} & \multirow{2}{*}{$\begin{array}{l}\text { N.Z. } \\
\text { lab no. }\end{array}$} & \multirow{2}{*}{$\begin{array}{c}\text { Horizon } \\
\text { desig. }\end{array}$} & \multirow{2}{*}{$\begin{array}{c}\text { Sample } \\
\text { depth } \\
(\mathrm{cm})\end{array}$} & \multicolumn{2}{|c|}{ Isotopes } & \multicolumn{9}{|c|}{ Chemical Properties } \\
\hline & & & & $\begin{array}{c}\Delta^{14} \mathrm{C} \\
9_{00}\end{array}$ & $\begin{array}{c}\delta^{13} \mathrm{C} \\
\%_{00}\end{array}$ & $\begin{array}{l}\mathrm{C} \\
\%\end{array}$ & $\begin{array}{l}\mathrm{N} \\
\%\end{array}$ & $\mathrm{C} / \mathrm{N}$ & $\begin{array}{l}\text { CEC } \\
\text { me \% }\end{array}$ & $\begin{array}{c}\mathrm{pH}\left(\mathrm{H}_{2} \mathrm{O}\right) \\
\text { dry soil }\end{array}$ & $\begin{array}{l}\mathrm{pH}\left(\mathrm{H}_{2} \mathrm{O}\right) \\
\text { moist soil }\end{array}$ & $\begin{array}{l}\text { Total P } \\
\text { mg \% }\end{array}$ & $\begin{array}{l}\text { Org. P } \\
\text { mg \% }\end{array}$ & $\begin{array}{c}\text { Inorg. } P \\
\text { mg \% }\end{array}$ \\
\hline $8856 \mathrm{~A}$ & 4533 & Ah1 & $0-13$ & $145.0 \pm 4.4$ & -26.2 & 2.3 & 0.19 & 12 & 11.1 & & 5.9 & 89 & 38 & 51 \\
\hline 8856B & 4534 & Ah2 & $13-22$ & $14.8 \pm 3.5$ & -26.3 & 1.7 & 0.15 & 11 & 11.4 & & 6.2 & 81 & 42 & 39 \\
\hline $8856 \mathrm{C}$ & 4535 & $\mathrm{Bw}(\mathrm{f})$ & $22-32$ & $-46.9 \pm 5.3$ & -24.8 & 1.0 & 0.09 & 11 & 9.5 & & 6.1 & 54 & 31 & 23 \\
\hline $8856 \mathrm{D}$ & 4536 & $\mathrm{BCx}$ & $32-50$ & $-264.4 \pm 6.7$ & -26.2 & 0.6 & 0.06 & 10 & 9.8 & & 6.1 & 53 & 26 & 27 \\
\hline $8856 \mathrm{E}$ & 4537 & $\mathrm{Cu}$ & $50-70$ & $-378.8 \pm 6.3$ & -26.0 & 0.2 & 0.02 & $*$ & 5.1 & & 6.2 & 67 & 8 & 59 \\
\hline
\end{tabular}


Site 19: Measurements (Continued)

\begin{tabular}{|c|c|c|c|c|c|c|c|c|c|c|}
\hline \multirow[b]{2}{*}{$\begin{array}{c}\text { S.B. } \\
\text { lab no. }\end{array}$} & \multirow[b]{2}{*}{$\begin{array}{l}\text { N.Z. } \\
\text { lab no. }\end{array}$} & \multirow[b]{2}{*}{$\begin{array}{c}\text { Horizon } \\
\text { desig. }\end{array}$} & \multirow[b]{2}{*}{$\begin{array}{c}\text { Sample } \\
\text { depth } \\
\text { (cm) }\end{array}$} & \multicolumn{6}{|c|}{ Physical-Mineralogical Properties } & \multirow[b]{2}{*}{ Comments } \\
\hline & & & & $\begin{array}{c}\text { Dry bulk } \\
\text { density } \\
t / \mathrm{m}^{3}\end{array}$ & $\begin{array}{l}\text { Stones } \\
(\% \mathrm{v} / \mathrm{v})\end{array}$ & $\begin{array}{c}\% \text { Sand } \\
2.0-0.02 \\
\mathrm{~mm}\end{array}$ & $\begin{array}{c}\% \text { Silt } \\
0.02-0.002 \\
\mathrm{~mm}\end{array}$ & $\begin{array}{c}\% \text { Clay } \\
<0.002 \\
\mathrm{~mm}\end{array}$ & $\begin{array}{l}\text { Clay minerals } \\
\text { (topsoil only) }\end{array}$ & \\
\hline $8856 \mathrm{~A}$ & 4533 & Ah1 & $0-13$ & 1.12 & 0 & 61 & 20 & 19 & \multirow{5}{*}{$\begin{array}{l}\text { Predominantly: } \\
\text { mica } \\
\text { Small amounts of: } \\
\text { mica-vermiculite, } \\
\text { mica-HIV, kaolin }\end{array}$} & \multirow{5}{*}{$\begin{array}{l}\text { Blank spaces in tables } \\
\text { indicate no available data. } \\
{ }^{*} \mathrm{C} / \mathrm{N} \text { ratio not calculated } \\
\text { where } \mathrm{N}<0.05 \text {. } \\
\text { †CEC = cation exchange } \\
\text { capacity; me \% = c mol(+) } \\
\mathrm{kg}^{-1}\end{array}$} \\
\hline 8856B & 4534 & Ah2 & $13-22$ & 1.25 & $\overline{0}$ & 59 & 22 & 19 & & \\
\hline $8856 \mathrm{C}$ & 4535 & $\mathrm{Bw}(\mathrm{f})$ & $22-32$ & 1.45 & 0 & 56 & 24 & 20 & & \\
\hline $8856 \mathrm{D}$ & 4536 & $\overline{B C x}$ & $32-50$ & 1.69 & 0 & 58 & 21 & 21 & & \\
\hline $8856 \mathrm{E}$ & 4537 & $\mathrm{Cu}$ & $50-70$ & 1.47 & $\overline{0}$ & 72 & 24 & 4 & & \\
\hline
\end{tabular}

